\title{
Habitat preferences, foraging behaviour and bycatch risk among breeding sooty shearwaters Ardenna grisea in the Southwest Atlantic
}

\author{
Anne-Sophie Bonnet-Lebrun ${ }^{1,2,3,8, *}$, Paulo Catry ${ }^{1}$, Tyler J. Clark ${ }^{4,9}{ }^{4}$ Letizia Campioni ${ }^{1}$, \\ Amanda Kuepfer ${ }^{5,6,7}$, Megan Tierny ${ }^{6}$, Elizabeth Kilbride ${ }^{4}$, Ewan D. Wakefield ${ }^{4}$ \\ ${ }^{1}$ MARE - Marine and Environmental Sciences Centre, ISPA - Instituto Universitário, Rua Jardim do Tabaco 34, \\ 1149-041 Lisboa, Portugal \\ ${ }^{2}$ Department of Zoology, University of Cambridge, Cambridge CB2 3EJ, UK \\ ${ }^{3}$ Centre d'Ecologie Fonctionnelle et Evolutive CEFE UMR 5175, \\ CNRS - Université de Montpellier - Université Paul-Valéry Montpellier-EPHE, 34293 Montpellier cedex 5, France \\ ${ }^{4}$ Institute of Biodiversity, Animal Health and Comparative Medicine, University of Glasgow, Glasgow G12 8QQ, UK \\ ${ }^{5}$ FIFD — Falkland Islands Fisheries Department, Falkland Islands Government, PO Box 598, Stanley, Falkland Islands, \\ FIQQ 1ZZ, UK \\ ${ }^{6}$ SAERI - South Atlantic Environmental Research Institute, Stanley, Falkland Islands, FIQQ 1ZZ, UK \\ ${ }^{7}$ Environment and Sustainability Institute, University of Exeter, Penryn Campus, Penryn TR10 9FE, UK \\ ${ }^{8}$ Present address: British Antarctic Survey, High Cross, Madingley Road, Cambridge CB4 0ET, UK \\ ${ }^{9}$ Present address: Wildlife Biology Program, Department of Ecosystem and Conservation Sciences, \\ W.A. Franke College of Forestry and Conservation, University of Montana, 32 Campus Drive, Missoula, Montana 59812, USA
}

\begin{abstract}
Pelagic seabirds are important components of many marine ecosystems. The most abundant species are medium/small sized petrels $(<1100 \mathrm{~g})$, yet the sub-mesoscale $(<10 \mathrm{~km})$ distribution, habitat use and foraging behaviour of this group are not well understood. Sooty shearwaters Ardenna grisea are among the world's most numerous pelagic seabirds. The majority inhabit the Pacific, where they have declined, partly due to bycatch and other anthropogenic impacts, but they are increasing in the Atlantic. To evaluate the sub-mesoscale habitat preferences (i.e. the disproportionality between habitat use and availability), diving behaviour and bycatch risk of Atlantic breeders, we tracked sooty shearwaters from the Falkland Islands during late incubation and early chick-rearing with GPS loggers $(n=20)$, geolocators $(n=10)$ and time-depth recorders $(n=10)$. These birds foraged exclusively in neritic and shelf-break waters, principally over the Burdwood Bank, $350 \mathrm{~km}$ from their colony. Like New Zealand breeders, they dived mostly during daylight, especially at dawn and dusk, consistent with the exploitation of vertically migrating prey. However, Falkland birds made shorter foraging trips, shallower dives, and did not forage in oceanic waters. Their overlap with fisheries was low, and they foraged at shallower depths than those targeted by trawlers, the most frequent fishing vessels encountered, indicating that bycatch risk was low during late incubation/early chick-rearing. Although our results should be treated with caution, they indicate that Atlantic and Pacific sooty shearwaters may experience markedly differing pressures at sea. Comparative study between these populations, e.g. combining biologging and demography, is therefore warranted.
\end{abstract}

KEY WORDS: Benthic-pelagic coupling $\cdot$ Dual foraging $\cdot$ Marine protected areas $\cdot$ Diving behaviour

${ }^{*}$ Corresponding author:

anne-sophie.bonnet-lebrun@normale.fr
(C) The authors 2020. Open Access under Creative Commons by Attribution Licence. Use, distribution and reproduction are unrestricted. Authors and original publication must be credited.

Publisher: Inter-Research · www.int-res.com 


\section{INTRODUCTION}

Pelagic seabirds are highly abundant and mobile consumers, with some species migrating between hemispheres to exploit seasonal peaks in prey abundance associated with habitat features, where they sometimes aggregate in large numbers (Shaffer et al. 2006, Hedd et al. 2012). Recently, bird-borne tracking has allowed many larger species to be observed remotely. However, due to the size of tracking devices, many aspects of the distribution, habitat selection and foraging ecology of medium and small petrels $(<1100 \mathrm{~g})$, which account for the majority of the world's pelagic seabirds, remain poorly resolved, especially at the sub-mesoscale $(<100 \mathrm{~km})$ (Rodríguez et al. 2019). This information is important because of the roles these species play in pelagic ecosystems (Brooke 2004) and because many species face numerous threats on land and at sea, including those from fisheries bycatch, introduced predators, climate change, breeding habitat loss, pollution, resource depletion and direct exploitation (Dias et al. 2019). A need therefore exists to better understand foraging ecology by quantifying the distribution, habitat associations and potential exposure to anthropogenic threats.

The sooty shearwater Ardenna grisea is a mediumsized petrel (mass $\sim 0.8 \mathrm{~kg}$, wing span $\sim 1 \mathrm{~m}$ ). It is one of the world's most abundant and wide-ranging pelagic seabirds, with an estimated global population of around 19.0-23.6 million individuals (Newman et al. 2009). The vast majority breed on islands around New Zealand (Newman et al. 2009), migrating into the North Pacific during Austral winter (Shaffer et al. 2009). In addition, sooty shearwaters also breed on islands along Chile's Pacific coast, perhaps in substantial numbers (Reyes-Arriagada et al. 2007), but with considerable uncertainty (Newman et al. 2009), and in the southwest Atlantic, around Tierra del Fuego and the Falkland Islands (Lawton et al. 2006, Clark et al. 2019). The latter population comprises around 170000 breeding pairs, $85 \%$ of which breed in 1 colony, Kidney Island (Clark et al. 2019). Tracking suggests that the majority of the Falkland breeding population migrates into the northwest Atlantic in the Austral winter (Hedd et al. 2012), with a small proportion wintering in the Benguela upwelling (E. D. Wakefield unpubl. data).

Sooty shearwaters are currently listed as 'Near Threatened' by the IUCN due to substantially reduced breeding populations in New Zealand between the 1960s-1970s and the 1990s-2000s (Newman et al. 2009, BirdLife International 2019). The reasons for these declines remain unclear but may include predation by non-native predators at breeding colonies (Newman et al. 2008, 2009), direct harvesting for food (Newman et al. 2009), fisheries bycatch (Uhlmann 2003) and climatic variation (Hyrenbach \& Veit 2003), although it is not clear if or how locally observed climatic correlations reflect causal linkages between climate and demography (Lyver et al. 1999, Clucas et al. 2012). In marked contrast, the number of sooty shearwaters breeding on Kidney Island (by far their largest breeding colony in the Falklands) has increased approximately 10 -fold in the past 2 decades (Clark et al. 2019). This may be due in part to the recovery of the species' tussac grass breeding habitat, which was formerly depleted due to harvesting and fires (Woods 1970, Clark et al. 2019). However, numbers are also thought to be increasing on nearby islands following rodent eradications there, so it remains unclear whether these population changes are due to breeding site effects, impacts at sea or both (unlike sooty shearwaters from New Zealand, Atlantic breeders are not harvested). Moreover, it is unclear how much the Atlantic population is at risk from bycatch. It is therefore important to understand the distribution and behaviour of sooty shearwaters in the Southwest Atlantic.

Vessel-based studies, concentrated in the North Pacific (Briggs \& Chu 1986, Briggs et al. 1987, Wahl et al. 1989, Santora \& Sydeman 2015), but also in the Southern Ocean (Phillips 1963) and the North Atlantic (Brown 1986), indicate that sooty shearwaters inhabit both neritic/shelf-slope waters and major oceanic frontal and cold upwelling zones, in the mid- to high latitudes, migrating between the southern and northern hemispheres to exploit seasonally abundant prey within these habitats. Year-round tracking has shown that during the breeding season, habitat use differs markedly between the Pacific and Atlantic populations (Shaffer et al. 2006, 2009, Hedd et al. 2012, 2014). Sooty shearwaters provisioning 30-75 d old chicks in New Zealand used not only local neritic, but also distant oceanic habitats, such as the Polar Front, visiting oceanic waters on trips of long duration and neritic habitats mainly on short trips (Shaffer et al. 2009). In contrast, Falkland breeders confined their foraging largely to the neritic waters of the Patagonian Shelf (Hedd et al. 2014), despite productive oceanic features, such as the Polar Front, lying well within their potential range.

The Patagonian Shelf is one of the world's most extensive and productive areas of neritic water (Longhurst 1998), supporting large populations of seabirds and marine mammals (Croxall \& Wood 2002, Acha et al. 2004). Geolocator tracking suggests that sooty 
shearwaters visit the southern part of the shelf, including the Burwood Bank/Banco Namuncurá (hereafter, Burdwood Bank, Fig. 1), during some stages of the breeding cycle (Hedd et al. 2014), but their finescale habitat associations remain unclear. Burdwood Bank is a shallow bank (minimum depth $\sim 50 \mathrm{~m}$ ), approximately $34000 \mathrm{~km}^{2}$ in extent, broadly delineated by the $200 \mathrm{~m}$ isobath, lying on the southern flank of the Patagonian shelf, from which it is partially separated by the Falklands Trough (maximum depth $\sim 3000 \mathrm{~m}$ ) (Schejter et al. 2016). The cold, relatively saline Antarctic Circumpolar Current (ACC) flows along the southern slope of the bank, with offshoots flowing north around the western and eastern sides of the bank, the latter forming the Falklands Current (Combes \& Matano 2018, Piola et al. 2018). The Patagonian shelf-break front is a persistent thermohaline discontinuity, usually located between the 90 and $100 \mathrm{~m}$ isobaths, separating cool/saline ACC/ Falkland Current waters from warmer, less-saline shelf water (Acha et al. 2004). Due to this feature, the shelf-break is characterised by relatively high primary and secondary production. In addition, Burdwood Bank itself has a particularly rich and diverse benthos (Schejter et al. 2016).

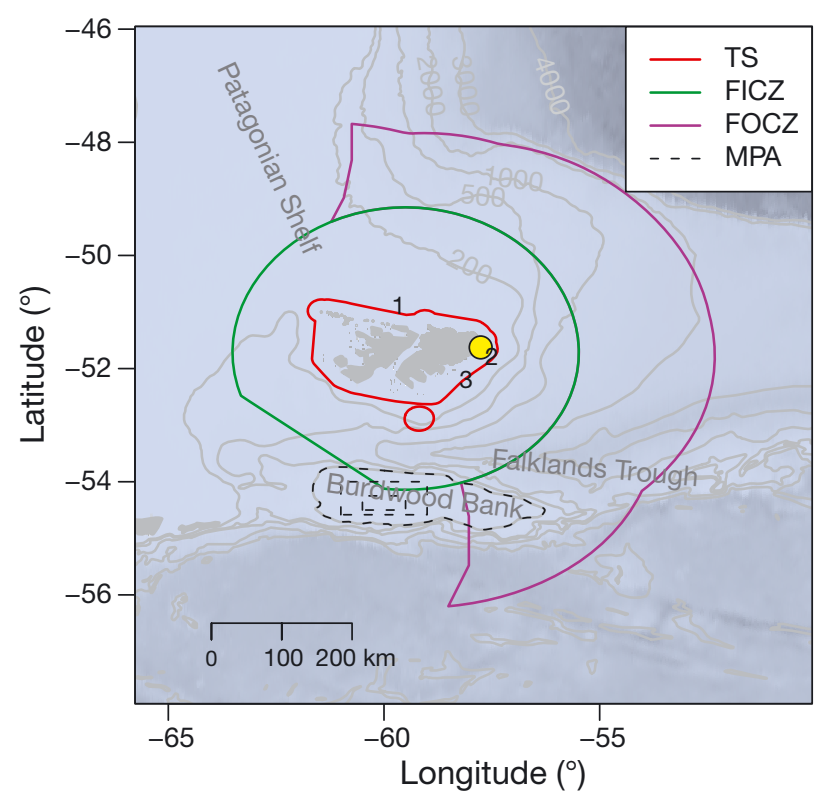

Fig. 1. Study area and locations mentioned in the text: Yellow circle, Kidney Island; 1, Pebble Island; 2, Port Stanley; 3 , Lively Island. TS: Falkland Territorial Sea; FICZ: Falkland Islands Interim Conservation and Management Zone; FOCZ: Falkland Islands Outer Conservation Zone; MPA: the core, buffer and transition zones of the Argentinian NamuncuráBurdwood Bank Marine Protected Area (partially in disputed waters)
Like many seabirds, sooty shearwaters are impacted by bycatch associated with fisheries. Although they are bycaught on longlines relatively infrequently compared to some Procellariiformes, their tendency to feed below the surface makes them vulnerable to bycatch in nets (Uhlmann 2003, Anderson et al. 2011). Before 1991, they were caught in large numbers in drift nets in the Pacific and Atlantic (Uhlmann 2003, Uhlmann et al. 2005). Although these fisheries are now much reduced due to a global moratorium, there is evidence that sooty shearwaters are also bycaught by trawlers (Uhlmann 2003), including those operating around the Falklands (Quintin 2014, Kuepfer 2017, Kuepfer et al. 2018) and inside the Argentine economic exclusion zone (EEZ) (González-Zevallos et al. 2007). Dive and distribution data, together with data on the distribution of fishing effort, have been used to assess where and at what depths this is most likely to occur (Le Bot et al. 2018).

Global positioning system (GPS) loggers are now small enough to track medium-sized petrels with an accuracy of $\sim 5 \mathrm{~m}$ (Waugh et al. 2016, Schoombie et al. 2018). Here, we employed this technology, together with temperature-depth recorders (TDRs), to record the movements and behaviour of sooty shearwaters breeding in the Falkland Islands during late incubation and early chick-rearing. We aimed first to describe the sub-mesoscale foraging distribution and habitat preferences (defined as the disproportionality between habitat use and availability; Aarts et al. 2008) of sooty shearwaters in the Falkland Islands, which we contrast with that of sooty shearwaters in their core range around New Zealand. Second, we aimed to assess the potential exposure of sooty shearwaters to the principal fisheries in the study area during this period.

\section{MATERIALS AND METHODS}

\subsection{Data collection}

We carried out fieldwork at Kidney Island $\left(51^{\circ} 38^{\prime} \mathrm{S}, 57^{\circ} 45^{\prime} \mathrm{W}\right.$, Fig. 1$)$, in the southeast of the Falklands, under licence from the Falkland Islands Government (licence R09/2016). Kidney Island is thought to be the largest sooty shearwater colony in the archipelago ( 140 000 occupied burrows), holding $\sim 85 \%$ of the Falkland's known breeding population (Clark et al. 2019). On average, eggs are laid on Kidney Island on 22 November $( \pm 2 \mathrm{~d}, \mathrm{SD})$ and hatch on 18 January ( \pm 6 d) (Hedd et al. 2014). Adults com- 
mence post-breeding migration in late March to early April (Hedd et al. 2012). We deployed and recovered loggers during late incubation and early chick-rearing, when sooty shearwaters are least likely to abandon their breeding attempt due to handling and are relatively easy to capture (for details on bird captures, see Text S1 in the Supplement at www.int-res.com/articles/suppl/m651p163_supp.pdf). Geolocator tracking indicates that male and female sooty shearwaters can have differing distributions during some life history stages (Hedd et al. 2014). On recapture, we therefore took a $1 \mathrm{ml}$ sample of blood from an interdigital blood vessel in the foot and stored half in absolute ethanol for molecular sexing, which was carried out subsequently in the laboratory using methods adapted from Fridolfsson \& Ellegren (1999) (see Text S1).

In order to monitor the sub-mesoscale distribution, behaviour and habitat use of sooty shearwaters, we used GPS loggers (nanoFix-GEO, PathTrack), programmed to record locations every 15 or $40 \mathrm{~min}$ with an accuracy $\leq 5 \mathrm{~m}$, to track 25 birds. To reduce interference to flight and diving (Vandenabeele et al. 2014, 2015), these loggers were designed with a low, flat profile (length $72 \mathrm{~mm}$, width $21 \mathrm{~mm}$, depth $7 \mathrm{~mm}$ ) and were attached to the mantle feathers, close to the birds' centre of gravity, using Tesa tape. Logger mass, including attachment tape, was $16 \mathrm{~g}$, equivalent to $2.09 \pm 0.44(\mathrm{SD}) \%$ body mass (range $1.54-$ $2.81 \%$ ). GPS loggers were deployed from 6-12 January 2017 and recovered between 14 and 21 January, after an average of $7 \mathrm{~d}$ (range 3-12 d).

In order to estimate depth utilisation and detect temporal patterns in dive activity, we used timedepth recorders (G5 TDR, CEFAS Technology; $2.7 \mathrm{~g}$; $31 \times 8 \times 8 \mathrm{~mm}$; accuracy $\pm 0.1 \mathrm{~m} ; 1 \mathrm{~Hz}$ sampling in 5 min bursts, recurring every $122 \mathrm{~min}$ ). Simultaneous deployment of GPS and TDR loggers would have resulted in total logger mass of $>3 \%$ of body mass, which could have biased behaviour and compromised the birds' welfare (Phillips et al. 2003). We therefore used considerably lighter but less accurate geolocation and wet/dry activity (GLS) loggers (Intigeo-F100, Migrate Technology; $1 \mathrm{~g} ; 14 \times 8 \times 6 \mathrm{~mm}$ ) to determine whether the distribution of the TDRequipped birds was similar to that of the GPStracked birds. Between 11 and 15 January 2017, we deployed TDRs and GLS loggers simultaneously (1 on each leg) on 14 birds. Each logger was attached to an elliptical plastic ring, with the long axis of the logger parallel to the tarsus. Total instrument mass, including attachment materials, was $6.7 \mathrm{~g}$, equivalent to $0.79 \pm 0.18 \%$ body mass (range $0.66-1.18 \%$ ).
We attempted to recover these loggers in January and October 2018 and in January 2019.

We identified putative foraging locations using Hidden Markov-chain Models (HMM) fitted to step lengths and turning angles in the GPS tracks using the R package 'moveHMM' (Michelot et al. 2016). We assumed 3 unobserved behavioural states: resting (small step length/high angle concentration, i.e. few turns), foraging (medium step length/low angle concentration, i.e. many turns) and commuting (large step length/high angle concentration) (see Text S1 and Table S1 for details). Prior to this and subsequent analyses, we used the 'redisltraj' function in the 'adehabitatLT' package (Calenge 2015) to resample the tracking data to a constant interval of $40 \mathrm{~min}$.

\subsection{Observed shearwater distribution}

It was impracticable to monitor the burrows of the GPS-tracked birds throughout the study, so it is unclear if and when the eggs of incubating tagged birds hatched. However, exploratory analysis showed no difference in the distribution at sea of birds incubating vs. those rearing chicks at the time of tagging. We therefore pooled data from incubating and chickrearing birds for analysis. We transformed locations to Lambert azimuthal equal area coordinates and then estimated each bird's utilisation distribution (UD; Fieberg \& Kochanny 2005) by calculating the kernel density of that bird's locations on a $2 \mathrm{~km}$ grid using the 'adehabitatHR' package (Calenge 2006), with a fixed smoothing parameter of $7.5 \mathrm{~km}$. We then calculated the mean UD across birds, which we refer to as the observed UD. We did this both for all locations and for foraging locations only. In order to estimate how well this represented the distribution of birds from the colony as a whole during the study period, we calculated the representativity following Lascelles et al. (2016). In brief, we randomly selected $\mathrm{n}$ birds among the $\mathrm{N}$ tracked birds, calculated the UD for this group as described above and then calculated the inclusion, defined as the proportion of locations of the remaining birds falling within a given percentage UD volume contour. We repeated this 100 times, for $n=\{1,2, \ldots, N-1\}$, using the 50, 75 and $95 \%$ UD volume contours. We then modelled the relationship between inclusion and $n$, for each UD volume contour level using nonlinear regression, and thereby estimated the height of the asymptote. Finally, we calculated the representativity of our sample, which is defined as inclusion at the observed sample size $(\mathrm{N})$, expressed as a percentage of inclusion at the 
asymptote. The minimum sample required to estimate a given UD volume contour perfectly occurs when representativity reaches $100 \%$.

\subsection{Habitat modelling framework}

In order to quantify the foraging habitat preferences (sensu Aarts et al. 2008) of sooty shearwaters and to predict their population-level distribution during the tracking period, we built 3 binomial generalised additive models (GAMs). Model I was designed to estimate habitat preference, whereas Models IIa and IIb were designed to predict usage. In all models, the response comprised the GPS-observed locations of birds (ones) matched by randomly generated pseudoabsence locations (zeros) (Aarts et al. 2008). We modelled this response as a function of smooths of explanatory covariates using the 'mgcv' package in $\mathrm{R}$ (Wood 2017). Initially, we attempted to model individual-level responses to habitat by specifying bird-level random slopes (i.e. generalised additive mixed model; GAMM). Unfortunately, these models frequently failed to converge; therefore, following similar studies (e.g. Raymond et al. 2015, Baylis et al. 2019), we modelled fixed-effects only (GAM). However, to account for unequal sampling across individuals due to different logger deployment durations, we specified prior weights on the contribution of the data to the log likelihood, calculated for each individual as the inverse of the number of locations available, and then normalised across individuals following recommendations from the 'mgcv' package using the formula: $x \rightarrow$ $x /$ mean $(x)$ (that is, all values of $x$ were converted to $x$ divided by the mean of $x$ ).

Model I was fitted to foraging locations. Space use by central-place foraging seabirds is known to be limited not only by habitat preference (where habitat is assumed to be a proxy for prey availability), but also by accessibility and competition (Wakefield et al. 2011, 2017). In the case of very large or isolated colonies, both accessibility and competition are largely dependent on colony distance (Bolton et al. 2019). In order to avoid these distance-dependent effects confounding habitat preference, we generated pseudo-absences (i.e. locations where the birds could have been observed but were not) for Model I by simulating tracks with the same central-place constraint and distribution of trip durations and speeds as the observed tracks (Raymond et al. 2015) using a first-order vector-autoregressive model in the 'availability' package in R (Raymond et al. 2018). We generated 5 simulated trips for each observed trip and randomly assigned a subset of these locations as 'foraging' locations such that the ratio of observed to simulated foraging locations ('pseudo-absences') was 1:5 for each individual. In effect, this generates a null model in which the central place constraint is the same as in the observed data and birds forage randomly with respect to the environment. We then modelled observed and pseudo-absence locations as a function of environmental covariates (Model I).

As Model I evaluates habitat selection in the absence of distance effects and cannot therefore directly predict use in geographical space (as opposed to environmental space) (Aarts et al. 2008), we built Models IIa and IIb. These 2 models differed from Model I in 2 key respects: firstly, we randomly selected pseudo-absences from a spatially homogeneous Poisson distribution, bounded by 1.1 times the maximum distance to the colony (ratio of pseudoabsences to observed locations, 1:5). This implicitly assumes a null model of uniform space use. Secondly, we included minimum distance by sea to the colony, calculated using the package 'gdistance' in R (van Etten 2017), as an explanatory covariate. Model IIa was fitted to all observed shearwater locations, plus their matched pseudo-absences, and was therefore used to predict space use at sea across all behavioural states. Model IIb was fitted to foraging locations and their matched pseudoabsences only, and was used to predict foraging space use.

\subsection{Candidate habitat covariates and model structure}

Based on current understanding of habitat use by sooty shearwaters (McClatchie et al. 1989, Shaffer et al. 2009, Adams et al. 2012, Hedd et al. 2012, 2014, Santora \& Sydeman 2015), we considered that habitat preference may usefully be defined in the following environmental dimensions: (1) depth (from the ETOPO1 Global Relief Model, spatial resolution of 1 arc minute, downloaded from https://www.ngdc. noaa.gov/); (2) sea floor slope (calculated from depth using the terrain function in the 'raster' $\mathrm{R}$ package [Hijmans 2018] using 8 neighbouring cells for each focal cell); (3) mean sea surface temperature (SST) during January 2017 (averaged from daily NOAA Optimum Interpolation Sea Surface Temperature V2, spatial resolution of $0.1^{\circ}$, downloaded from https:// www.esrl.noaa.gov/); (4) monthly mean net primary production (NPP) (derived from MODIS Aqua data, spatial resolution of $4 \mathrm{~km}$, downloaded from http:// coastwatch.pfeg.noaa.gov). We assumed that each of 
these metrics could have additive effects on habitat selection. Hence, Model I took the form:

$$
\begin{aligned}
\eta_{i}= & b_{0}+s_{1}\left(\operatorname{depth}_{i}\right)+s_{2}\left(\text { depth slope }_{i}\right) \\
& +s_{3}\left(\mathrm{SST}_{i}\right)+s_{4}\left(\mathrm{NPP}_{i}\right)
\end{aligned}
$$

while Models IIa and IIb took the form:

$$
\begin{aligned}
& \eta_{i}=b_{0}+s_{1}\left(\operatorname{depth}_{i}\right)+s_{2}\left(\text { depth slope }_{i}\right)+s_{3}\left(\mathrm{SST}_{i}\right) \\
& +s_{4}\left(\mathrm{NPP}_{i}\right)+s_{5}(\text { Distance })
\end{aligned}
$$

$\eta_{i}$ is the linear predictor at the $i^{\text {th }}$ location and $s_{1,2,3} \ldots()$ are cubic regression splines with shrinkage. Shrinkage penalises large smoothing parameters during generalised cross-validation-based parameter estimation, allowing the effect of uninformative covariates to reduce to zero if necessary (Wood 2004). In addition, to reduce the chances of overfitting, we multiplied the effective degrees of freedom of smooths by 1.4 prior to parameter estimation (Kim \& Gu 2004).

\subsection{Analysis of dive behaviour}

We used the algorithm described by Merkel et al. (2016) to calculate the most likely locations of GLSand TDR-equipped birds given the light, temperature and activity data recorded by the GLS loggers (see Text S1). We then calculated the mean observed UDs of the TDR-equipped birds as described above, with a fixed smoothing parameter of $75 \mathrm{~km}$.

We extracted dive metrics (rate, duration, mean and maximum depth) from the TDR data using the algorithm described in Text S1. To facilitate comparison with dive indices reported in other studies (Shaffer et al. 2006, 2009, Dunphy et al. 2015), we present summary statistics for dives $\geq 1 \mathrm{~m}$ (Dunphy et al. 2015) and those $>2.5 \mathrm{~m}$ deep (Shaffer et al. 2009). Temporal trends through the breeding season and diel patterns in dive behaviour were modelled using GAMMs (Wood 2017; see Text S1). We used generalised linear mixed-effects models (GLMMs) with a similar structure to estimate mean dive indices and to model the relationship between maximum dive depth and dive duration (see Table 1).

\subsection{Overlap between shearwaters and fishing activity}

To assess the relative exposure of sooty shearwaters to bycatch risk, we obtained 2 spatial fishing effort data sets: (1) Global Fishing Watch (GFW) data, which are based on the automatic identification system (AIS) (Kroodsma et al. 2018), and span the entire study area, and (2) vessel monitoring systems (VMS) data from the Falkland Islands Fisheries Department (FIFD), which span Falkland waters only. Using these data (see Text S1), we calculated mean fishing effort by each gear type (trawlers, longliners and squid-jiggers) during (1) January 2017 and (2) January 2012-2018 on a $20 \mathrm{~km}$ resolution regular grid spanning the study area, subsequently scaling each grid such that it summed to 1, to obtain fishing effort UDs. We specified this grid resolution such that a bird anywhere in a cell would be able to detect the presence of a fishing boat anywhere else in the cell and potentially interact with it. The closest relative to sooty shearwaters for which we could find relevant data, the black-browed albatross Thalassarche melanophris, does so up to $30 \mathrm{~km}$ (Collet et al. 2015). Assuming that sooty shearwaters have a similar acuity, we specified a grid cell hypotenuse of $\sim 30 \mathrm{~km}$ (i.e. $20 \mathrm{~km}$ cell size). To assess the representativity of estimates based on AIS from GFW data and validate their use over the whole study area, we compared estimated maps of fishing effort with maps produced using VMS data within Falklands waters.

We used 2 approaches to quantify overlap between sooty shearwaters and fishing vessels and to assess where overlap was greatest. Firstly, we calculated the Bhattacharyya affinity (BA; Fieberg \& Kochanny 2005) between the UDs of foraging sooty shearwaters (SOSH) and those of each fishing activity:

$$
\mathrm{BA}=\sum_{x, y} \sqrt{\mathrm{UD}_{\mathrm{SOSH}}(x, y) \mathrm{UD}_{\text {fishing }}(x, y)}
$$

where BA ranges from 0 (no similarity between the distribution of birds and fishing activity) to 1 (identical distributions). We then plotted a simple index of the relative likelihood of foraging shearwaters encountering fishing activity, which we term the fisheries exposure index (FE):

$$
\operatorname{FE}(x, y)=\operatorname{UD}_{\mathrm{SOSH}}(x, y) \mathrm{UD}_{\text {fishing }}(x, y)
$$

We assume that FE is proportional to bycatch risk exposure (Hatch et al. 2016). We calculated these indices for mean fishing activity during January 2017 (the tracking period) and throughout January 2012-2018 (the period for which AIS data from GFW were available) vs. shearwater foraging UDs, both observed (based on the tracking data) and predicted (using Model IIb).

All analyses were carried out in R. 3.5.1 (R Core Team 2018). Unless otherwise stated, we report means \pm SD. 


\section{RESULTS}

\subsection{Foraging trip characteristics and distribution}

We were able to recapture 20 out of 25 GPSequipped sooty shearwaters (11 males, 8 females and 1 of unknown sex). Prior experience indicated that the GPS loggers on the uncaught birds would have been shed, either when the attachment tape failed or the mantle feathers moulted. GPS data from the tracked birds spanned 1-6 foraging trips (median, 1; total trips, 39). These were confined entirely to the Patagonian Shelf or shelf slope, with $97 \%$ of tracking locations recorded in areas shallower than $500 \mathrm{~m}$ and $87 \%$ in areas shallower than $200 \mathrm{~m}$. The distribution of maximum distance from the colony was bimodal (Fig. S1): trips were either relatively short $(\leq 150 \mathrm{~km}$ away from the colony), mostly following the Falklands coast to a maximum of $56.6 \pm 45.3 \mathrm{~km}$ from the colony (16.1 $\pm 3.67 \mathrm{~h}, 21$ complete trips), or relatively long ( $\geq 350 \mathrm{~km}$ away from the colony), up to $393.0 \pm$ $22.1 \mathrm{~km}$ from the colony $(70.4 \pm 36.8 \mathrm{~h}, 17$ complete trips; Fig. 2, Fig. S1). All birds foraged to the south of the colony, with the vast majority going south to Burdwood Bank, $350 \mathrm{~km}$ distant. Four males also made trips west, along the north coast of the archipelago, as far as Pebble Island, $\sim 150 \mathrm{~km}$ from the colony. Overall, however, there was no evidence of bimodality in trip durations (Fig. S1). For most birds, some

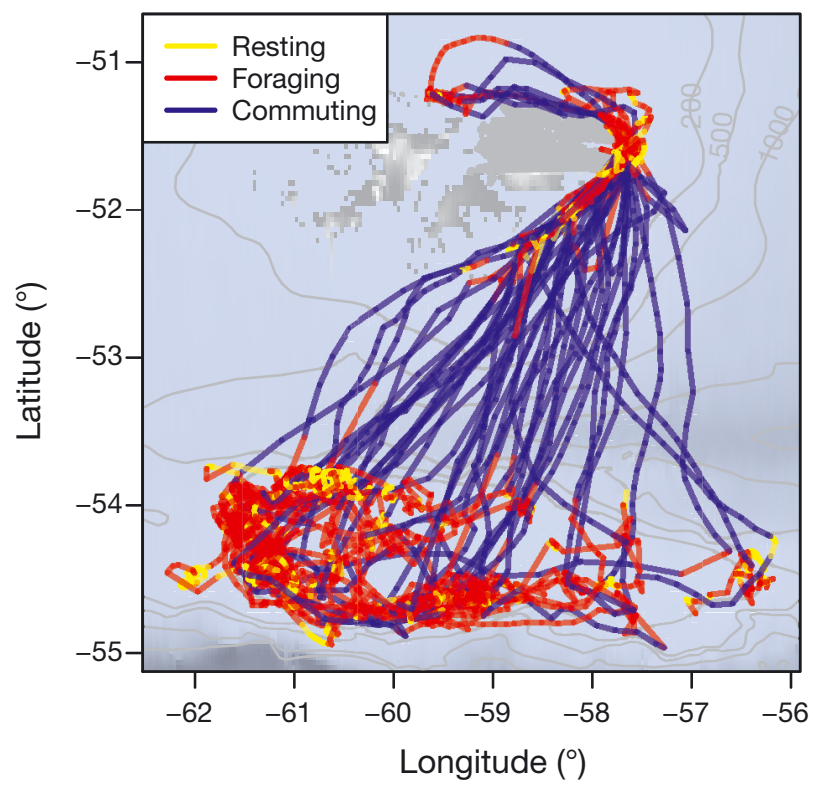

Fig. 2. GPS tracks of sooty shearwaters from Kidney Island during late incubation and early chick-rearing in 2017 (20 birds, 39 trips). Behaviour was classified based on speed and turning angle into 3 putative states using a hidden Markov model putative foraging locations were identified within $50 \mathrm{~km}$ of Kidney Island, and 1 female foraged exclusively between the colony and Lively Island, $60 \mathrm{~km}$ to the southwest, an area also used by several other birds en route to and from Burdwood Bank. Overall, the UDs of males and females were very similar (BA all behaviours $=0.89$; BA foraging $=0.88$; Fig. S2), so we pooled the sexes for subsequent analyses. Core areas of usage were (1) on the western half of Burdwood Bank, upslope of the western and southern shelf-break, just within the $200 \mathrm{~m}$ depth contour; (2) east of Lively Island on the east coast of the Falkland archipelago; and (3) around the colony (Fig. 2). The latter 2 areas are within the Falklands Territorial Sea, while the former is outside of it, largely outside the Falkland Islands Interim Conservation and Management Zone (FICZ) and the Falkland Islands Outer Conservation Zone (FOCZ), but within the Transition Zone of the Namuncurá-Burdwood Bank Marine Protected Area and the Argentine EEZ. Representativity analysis indicated that the size of our GPS tracking data set was sufficient to identify the core areas used by sooty shearwaters (50\% UD volume contour) accurately enough to capture $90.6 \%$ of mean colony-level spatial usage during the study period (Fig. S3). Equivalent representativity values were higher still (91.4 and 94.7\%) for the 75 and $95 \%$ UD volume contours, respectively.

\subsection{Foraging habitat preferences and predicted distribution}

Use-availability plots (Fig. S4) showed that GPStracked sooty shearwaters foraged disproportionately in cooler, shallower and more productive waters than those accessible to them from Kidney Island. However, only depth, SST and distance from the colony had strong effects in Model I, the model describing habitat preference (Fig. 3). Habitat preference peaked with respect to SST at $\sim 7.5$ and $10^{\circ} \mathrm{C}$. Preference decreased with depth (Fig. 3), the rate of decrease being greater from 0 to $500 \mathrm{~m}$ (i.e. from the coast to the upper shelf slope) than below this depth (i.e. from the upper shelf slope to the open ocean). Variation in preference with respect to distance from the colony was complex, but there was a notable minimum around $250 \mathrm{~km}$ from the colony, possibly corresponding to low usage in the Falklands Trough, not captured by other environmental indices (Figs. 2 \& 3).

Model IIa (fitted to all tracking data, plus pseudoabsences generated via a spatially uniform Poisson process) predicted that sooty shearwaters use the 

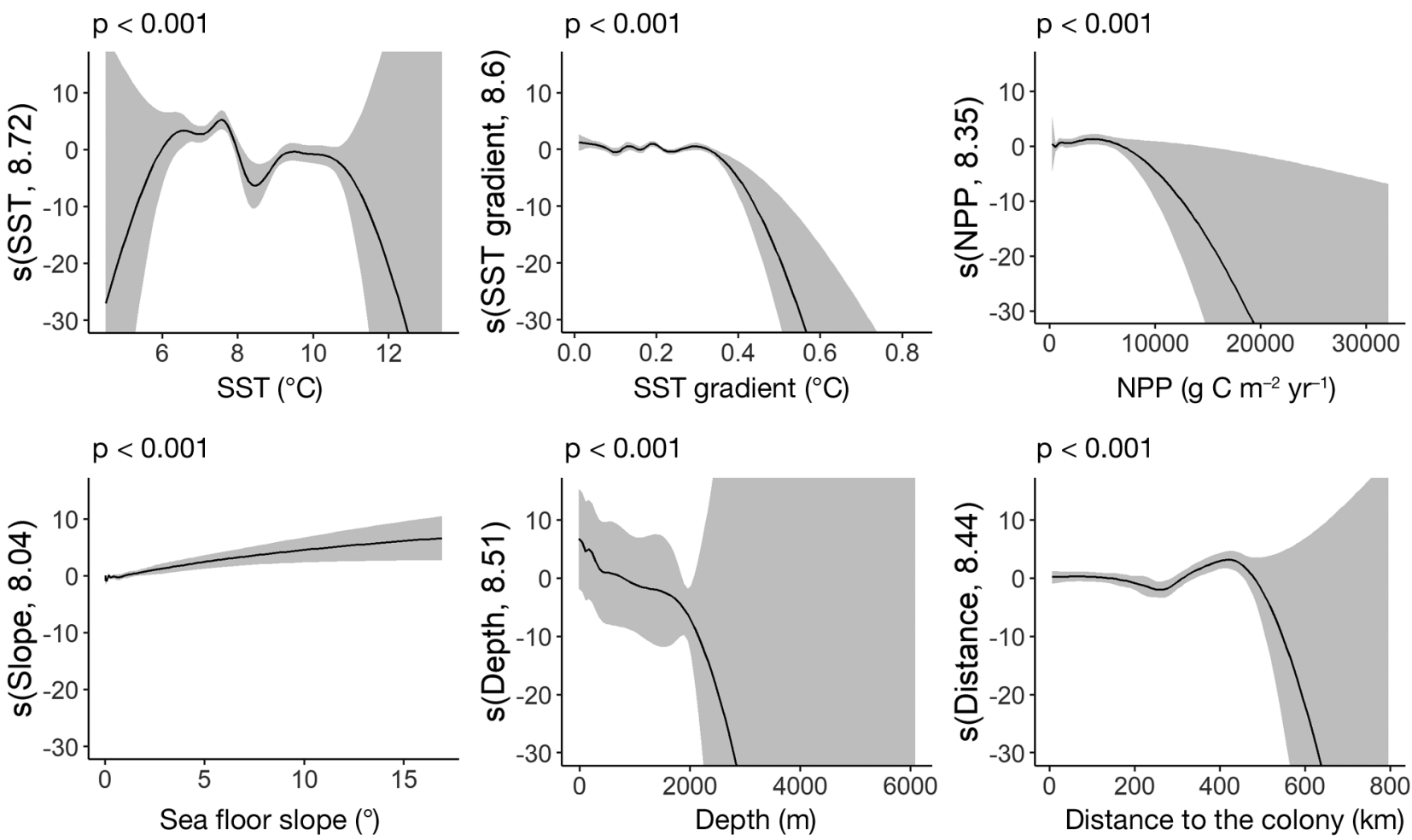

Fig. 3. Foraging habitat preference of sooty shearwaters GPS-tracked from Kidney Island during late incubation and early chick-rearing in 2017 estimated by Model I. $Y$-axis labels indicate estimated degrees of freedom of smooths, and p-values show their significance. Shaded areas indicate approximate $95 \%$ CIs. SST: sea surface temperature; NPP: net primary production

eastern part of Burdwood Bank more than we observed via GPS-tracking (cf. Figs. 2 \& 4). High usage was also predicted in coastal waters north and east of East Falkland. An area on the SE flank of the Falklands Trough, between the 500 and $1000 \mathrm{~m}$ depth contours, $130 \mathrm{~km}$ SE of the Falklands, was also indicated as one of moderate use.

The distribution of foraging sooty shearwaters predicted by Model IIb (fitted to putative foraging locations, plus pseudo-absences generated via a spatially uniform Poisson process) was similar, but very little use was predicted in the Falklands Trough. Tracking data showed that birds generally commuted rapidly over this area en route to and from Burdwood Bank (Fig. 2). Model IIb predicted higher foraging activity on the western and southern sides of Burdwood Bank than on its northern and eastern sides (Fig. 4), similar to the pattern observed in the tracking data (Fig. 2).

\subsection{Dive behaviour}

In January 2018, we were able to recapture 10 of the 14 TDR/GLS-equipped birds ( 5 females and 5 males). GLS data showed that these individuals remained on the Patagonian Shelf until between 27 February and 17 April 2017 (median commencement of post-breeding migration: 3 April; Table S2, Fig. S5). The following statistics summarise dive data from 15 January to the commencement of postbreeding migration, or to 3 April for birds that had not already begun migrating by that date (i.e. late incubation to the end of chick-rearing). The distribution of GLS-tracked birds during this period was similar to that of the GPS-tracked birds, with space use concentrated between the south coast of the Falklands and the northern side of Burdwood Bank (Fig. 2 and Fig. S6). In addition, parts of the Patagonian Shelf north of the Falklands and off the Argentine coast were visited intermittently, especially late in the breeding season. On average, $93 \%$ of dives detected were recorded completely (range across 10 individuals: $84-98 \%$ ). There were no significant differences in dive rate, depth or duration between males and females (GLMM p $<0.001$ in all cases; Table S3), so the sexes were pooled for all subsequent analyses. On average, birds made 2.9 dives $\mathrm{h}^{-1}$ to $\geq 1 \mathrm{~m}$ and 1.2 dives $\mathrm{h}^{-1}$ to $>2.5 \mathrm{~m}$ (Table 1). Maximum individual dive rates ranged from 48 to 84 dives $\mathrm{h}^{-1}$, respectively (Table S3). Birds were most likely to dive during day- 

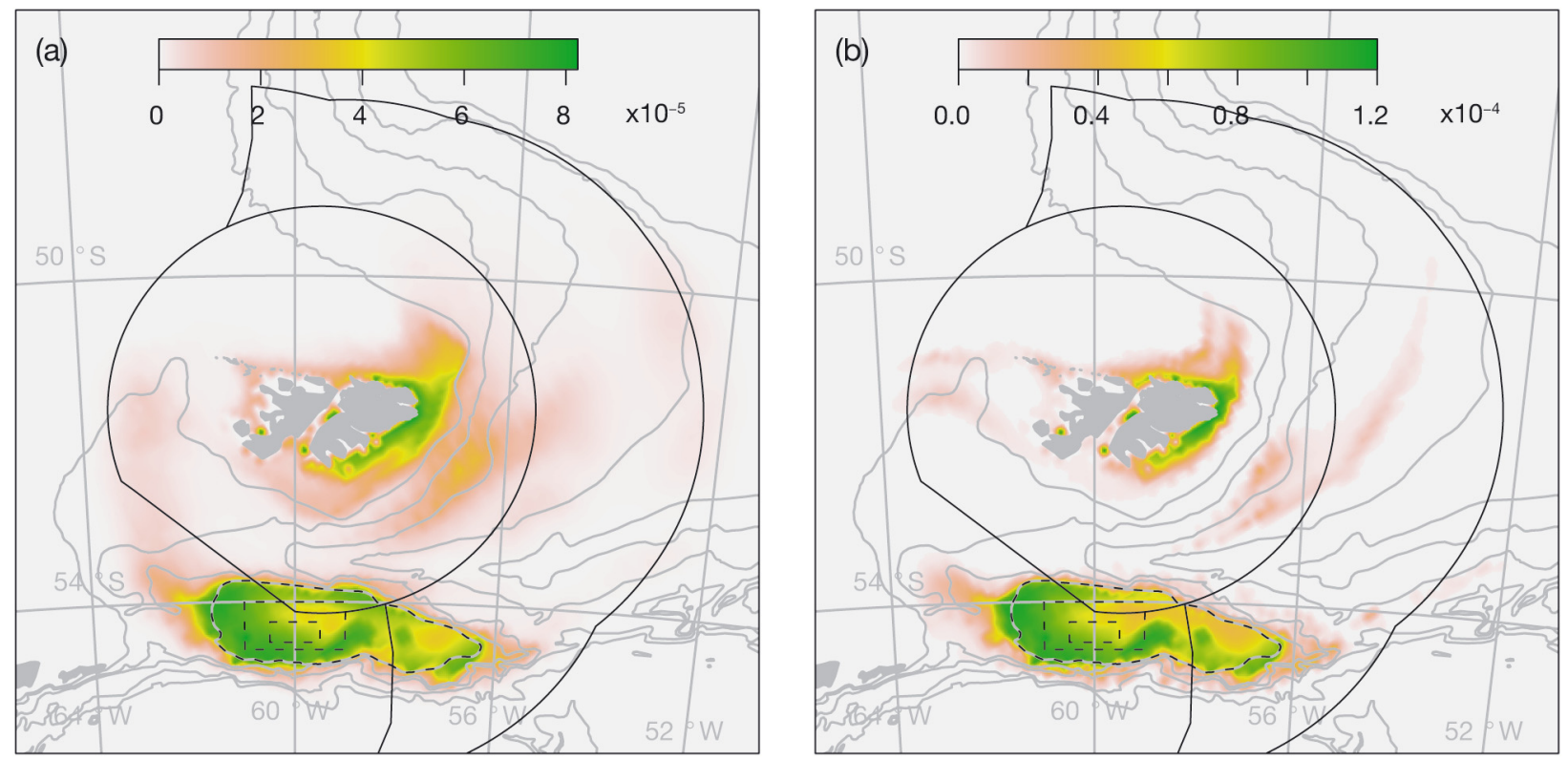

Fig. 4. Predicted utilisation distribution (probability density) of incubation and early chick-rearing stage sooty shearwaters from Kidney Island, during (a) all behavioural states (Model IIa) and (b) foraging (Model IIb). Solid black lines indicate Falkland Islands management zones (see Fig. 1); dashed black lines show the core, buffer and transition zones of the Argentinian Namuncurá-Burdwood Bank Marine Protected Area

light, with dive rates peaking around dawn and dusk (Fig. 5). Birds were slightly more likely to dive in the middle of the study period, but the temporal trend in dive rate was opposite. Hence, although recording bouts contained dives most frequently at the beginning of March (middle of the post-brood chickrearing period), the dive rate during bouts with dives fell to a minimum at this time. Only $32 \pm 17 \%$ of complete dives were $>2.5 \mathrm{~m}$ deep (range across individuals: $14-60 \%$ ). The maximum depth attained in complete dives $>2.5 \mathrm{~m}$ deep was strongly dependent on dive duration $(\max$. depth $[\mathrm{m}]=\exp [1.08+0.046 \times$ duration (s)]); marginal and conditional $\mathrm{R}_{\mathrm{GLMM}}^{2}$ [Nakagawa et al. 2017] $=0.66$ and 0.82 respectively; Table S4). On average, these dives reached $9.5 \mathrm{~m}$
(95\% CI: 8.4-10.8 m, Table 1). Maximum dive depths were similar across individuals (Table S3), and the maximum depth attained by any individual was $53.5 \mathrm{~m}$. Dives lasted between 3 and $82 \mathrm{~s}$. Both dive duration and maximum depth increased until 22 February and then decreased (Fig. 5). In addition, there was a weak diurnal pattern in dive depth, with dives being shallower on average at night than during the day (Fig. 5). However, the deepest dives overall occurred at dawn, and to a lesser extent, dusk (Fig. 6). Birds dived very little at night; between dusk and dawn, they spent $0.1 \%$ of their time below $5 \mathrm{~m}$ and $0.01 \%$ below $20 \mathrm{~m}$ (Fig. 6). In contrast, between dawn and dusk, they spent on average $1 \%$ of their time below $5 \mathrm{~m}, 0.1 \%$ below $10 \mathrm{~m}$ and $0.01 \%$ below $30 \mathrm{~m}$.
Table 1. Generalised linear mixed-effects model-based estimates of means and approximate $95 \%$ confidence intervals (plus range) of sooty shearwater dive indices for dives $\geq 1 \mathrm{~m}$ and $>2.5 \mathrm{~m}$ deep

\begin{tabular}{|cccccc|}
\hline Dive type & & $\begin{array}{c}\text { Duration } \\
(\mathrm{s})\end{array}$ & $\begin{array}{c}\text { Mean depth } \\
(\mathrm{m})\end{array}$ & $\begin{array}{c}\text { Maximum } \\
\text { depth }(\mathrm{m})\end{array}$ & $\begin{array}{c}\text { Rate } \\
\left(\text { dives }^{-1}\right)\end{array}$ \\
\hline \multirow{2}{*}{$\geq 1 \mathrm{~m}$} & Mean & 12.0 & 2.5 & 4.8 & 2.9 \\
& $95 \%$ CI & $9.5-15.1$ & $1.8-3.3$ & $3.9-6.1$ & $2.2-3.8$ \\
& Range & $3-82$ & $0.2-26.0$ & $1.0-48.5$ & 0,312 \\
& Mean & 21.0 & 5.3 & 9.5 & 1.2 \\
& 95\% CI & $18.5-23.8$ & $4.6-6.2$ & $8.4-10.8$ & $1.1-1.4$ \\
& Range & $3-82$ & $0.6-26.0$ & $2.6-48.5$ & $0-84$ \\
\hline
\end{tabular}

\subsection{Exposure of shearwaters to fishing activity}

Within the FICZ and FOCZ (where all fishing activity is thought to be monitored by VMS), the distribution of fishing effort based on GFW data was similar to that estimated using VMS data (Figs. S6 \& S7; BA and $\mathrm{R}^{2}$ and for GFW vs. VMS effort, averaged across years and gear types, were 0.73 and 
(a) Probability of diving
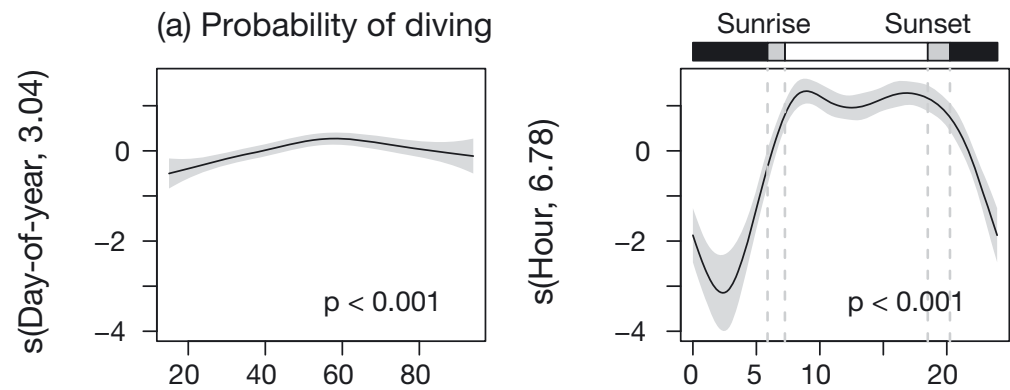

(b) Dive rate
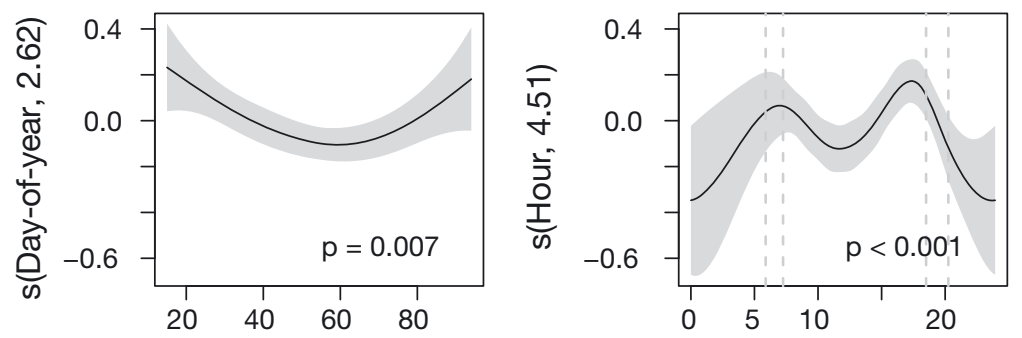

(c) Dive duration
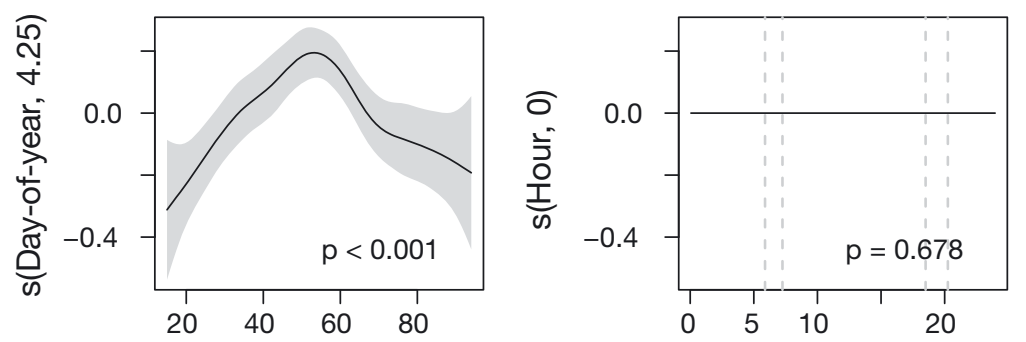

(d) Log(maximum dive depth)
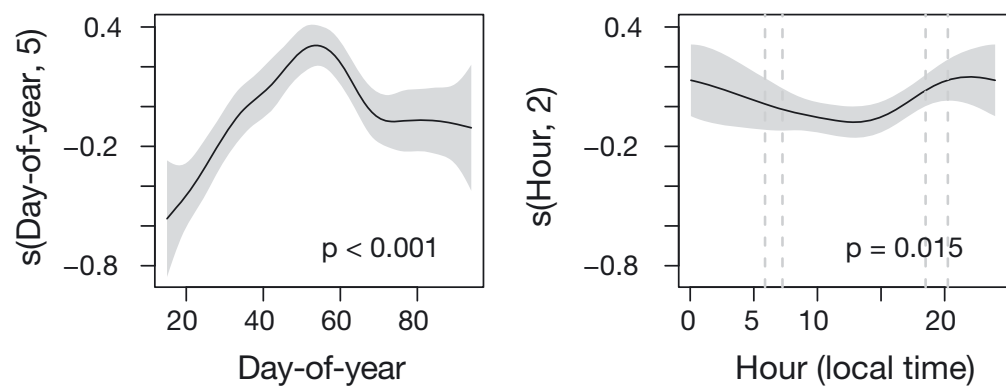

Fig. 5. Generalised additive mixed-effects models of (a) probability of diving within a recording burst (binomial errors and logit link function, intercept $=-3.28, \mathrm{SE} \pm 0.11$ ); (b) dive rate $\left(\log \left[\right.\right.$ dives $\left.\mathrm{h}^{-1}\right]$ ) during recording bursts with dives (Gaussian errors and identity link function, intercept = $0.825, \mathrm{SE} \pm 0.07$ ) (c) dive duration ( $\mathrm{s}$ ) during dives $>2.5 \mathrm{~m}$ deep (negative binomial errors and log link, intercept $=3.04, \mathrm{SE} \pm 0.06$ ); and (d) $\log$ (maximum dive depth $[\mathrm{m}]$ ) during dives $>2.5 \mathrm{~m}$ deep (Gaussian errors and identity link function, intercept $=2.18, \mathrm{SE} \pm 0.06$ ). $Y$-axis labels indicate estimated degrees of freedom of smooths and p-values show their significance. Shaded areas approximate $95 \%$ CIs. Dashed vertical lines in the right panels show times of sunrise and sunset during the study period (15 January to 4 April)
GFW but not VMS data identified a small amount of trawling effort east of Port Stanley, while in 2015 the opposite was true (Fig. S6). In both cases, the pattern was consistent with vessels slowly approaching or leaving port, rather than trawling. Despite these differences, the distribution of fishing effort averaged over the period 20122017 agreed closely between the 2 methods. We therefore only present the results of our analysis of fisheries risk exposures based on the GFW dataset, which has more complete spatial coverage within our study area than the VMS data. No squid-jiggers were detected in the areas used by sooty shearwaters during our study period (Fig. S6), so we did not evaluate this fishery.

In general, similarity between the UDs of shearwaters and those of trawlers or longliners was low (Fig. 7 and Fig. S8, BA $\leq 0.12$ for all comparisons). This indicates that during late incubation and early chick-rearing, sooty shearwaters breeding on Kidney Island were exposed to little risk of bycatch from these fisheries. The similarity between observed shearwater UDs and fishing UDs was generally greater than that between predicted shearwater UDs and fishing UDs (Fig. S8). Predicted (i.e. population-level) shearwater UDs were more widely distributed than the tracking-based UDs, resulting in greater similarity between observed shearwater UDs and fishing UDs than between predicted shearwater UDs and fishing UDs (Fig. S8). In January, sooty shearwaters had greater overlap with trawlers than with longliners (Fig. 7), especially over the western end of Burdwood Bank, inside the Argentine EEZ and off the east coast of East Falkland. There was no longlining in areas observed or predicted to be used by sooty shearwaters during January 2017. However, our results indicated that sooty shearwaters may have greater overlap with longliners during some 0.80 , respectively; see Table S5 for details). Notable exceptions were for trawling in 2014 and 2015. Spatial plots indicated that this was because in 2014 years, especially in the Falklands Trough, and around the shelf break of the eastern half of Burdwood Bank (Fig. 7). 


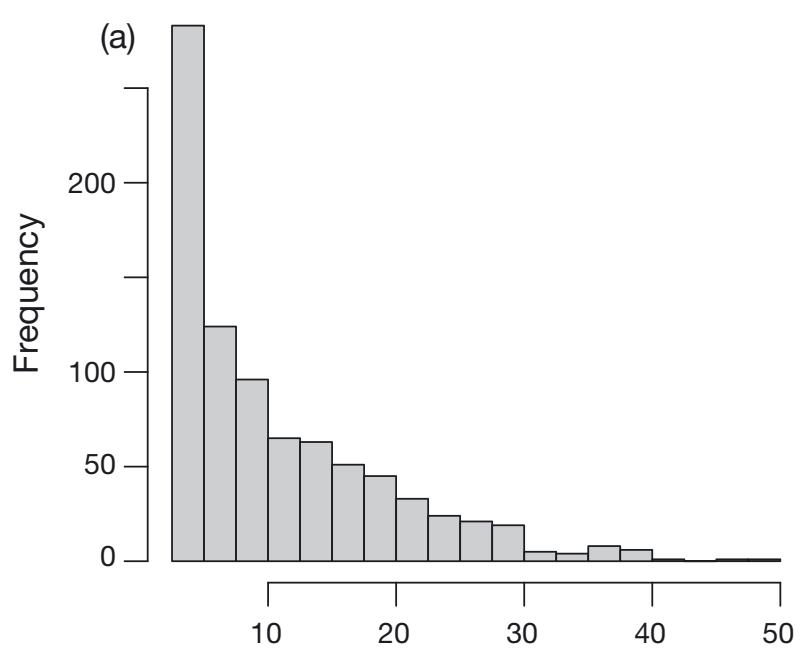

Maximum depth $(\mathrm{m})$

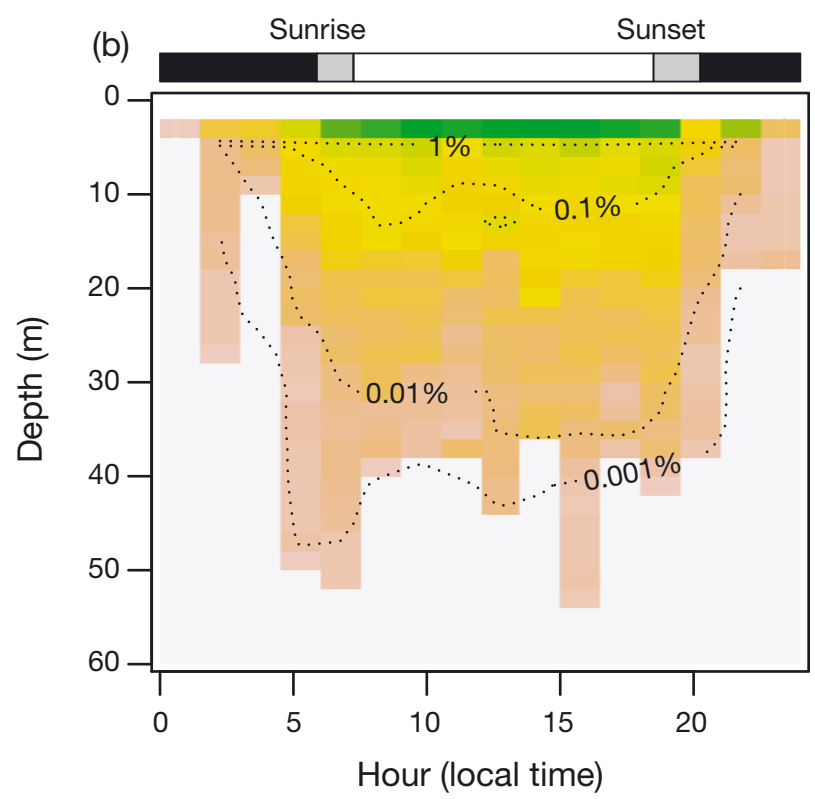

Fig. 6. Distribution of breeding sooty shearwater $(n=10)$ dive effort with depth between 15 January and 4 April. (a) Frequency of dives by maximum depth (dives $>2.5 \mathrm{~m}$ ) and (b) mean depth utilisation distribution. Contours indicate the depth below which a given percentage of time was spent, e.g. between 10:00 and 11:00 h, birds spent on average $\leq 0.01 \%$ of their time below $31 \mathrm{~m}$ (for clarity, utilisation above $2 \mathrm{~m}$, which ranged from $97-100 \%$, is not coloured). The horizontal bar indicates the local times of night (black), day (white) and sunrise and sunset (grey) during the study period

\section{DISCUSSION}

We GPS-tracked sooty shearwaters from the species' largest colony in the Falkland Islands during incubation and early chick-rearing. We found that birds foraged almost exclusively in neritic, and especially shelf-break, waters on Burdwood Bank, a shal- low rise on the southern margin of the Patagonian Shelf. This is in marked contrast to breeding sooty shearwaters tracked in the species' core range around New Zealand, where Shaffer et al. (2009) documented foraging farther from their colony, in both neritic and oceanic waters. Diel variation in dive activity of Falkland-breeding birds were similar to those from New Zealand, but their dives were shallower. Combining model predictions and data on fishing boat movements, our results indicated that the overlap between Falkland-breeding sooty shearwaters and fisheries was low during late incubation/early chick-rearing, but during this period, shearwaters had greater overlap with trawlers than with other types of fishing vessels.

\subsection{Foraging distribution and habitat preferences}

Previous studies have shown that it may be necessary to track relatively large numbers of individuals to characterise population-level space use by breeding waterbirds adequately, e.g. 80-130 for sea ducks, 29-73 for European shags Phalacrocorax aristotelis and 109-161 for black-legged kittiwakes Rissa tridactyla (Soanes et al. 2013, Roberts et al. 2018). It is therefore pertinent to consider how well our data represent the population as a whole. Representativity analysis (Lascelles et al. 2016) suggested that despite the relatively small sample of birds GPStracked in our study $(n=20)$, UD estimates based on these data likely captured $>90 \%$ the colony-level variation in space use in the study period (Fig. S3). This is because space use during our study was highly consistent across individuals, with all tracked birds foraging on Burdwood Bank, and only 4 spending any appreciable time foraging elsewhere (Fig. 2). Lower-resolution GLS tracking ( 2 locations $\mathrm{d}^{-1}$; spatial error: $186 \pm 114 \mathrm{~km}$ [Phillips et al. 2004] to $202 \pm$ $171 \mathrm{~km}$ [Shaffer et al. 2005]) during our study ( $\mathrm{n}=10$ birds; Fig. S5) and almost a decade previously ( $\mathrm{n}=$ 17; Hedd et al. 2014) were similar to the those of the birds GPS-tracked in our study, so our results may reflect the mean distribution across years. However, our sample remains small so it would be prudent to treat our results with caution and to test their generality by carrying out further GPS tracking in the Falklands. For example, our simulations suggest that to improve representativity of core areas of usage (i.e. the $50 \%$ UD volume contour) from 90 to 95 or $97.5 \%$, an additional 20 or 61 birds would need to be tracked, respectively (Table S6). 
UD Trawling, 2017

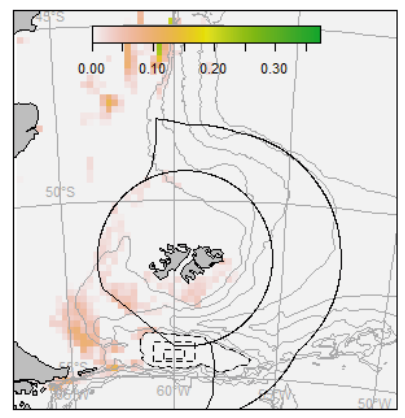

UD Longlining, 2017

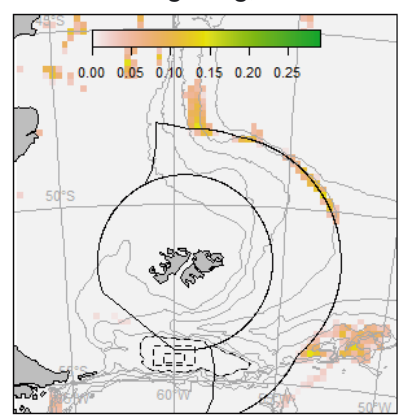

FE Trawling, 2017

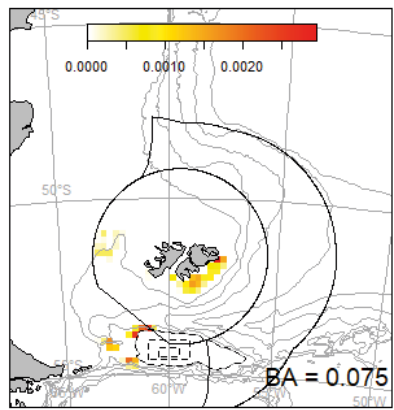

FE Longlining, 2017

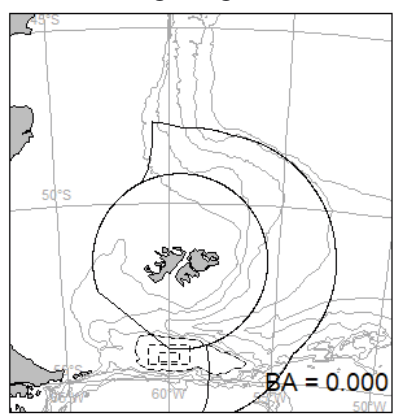

UD Trawling, 2012-2018

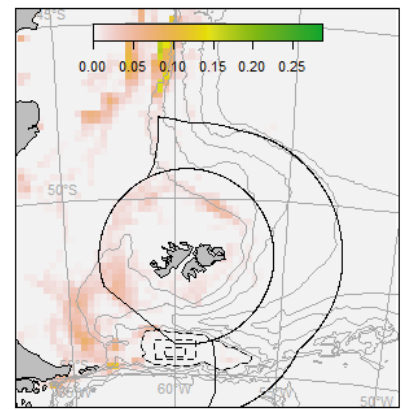

UD Longlining, 2012-2018

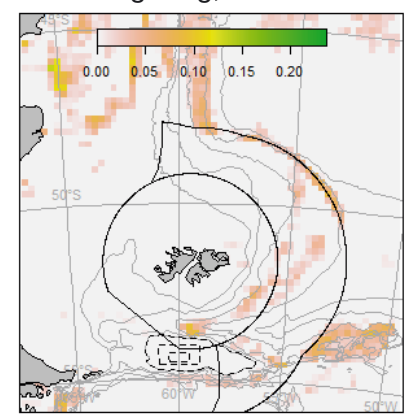

FE Trawling, 2012-2018

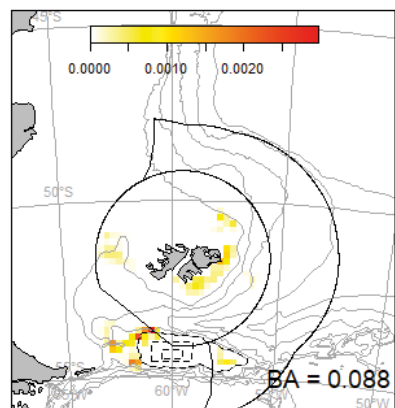

FE Longlining, 2012-2018

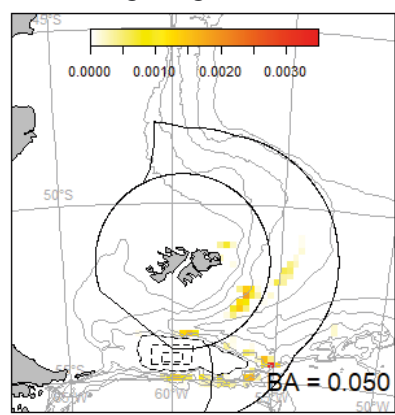

Fig. 7. Utilisation distribution (UD) of mean fishing effort in January 2017 and January 2012-2018 (estimated from data supplied by Global Fishing Watch) and the fishery exposure (FE) index for foraging shearwaters during late incubation and early chick-rearing, indicating areas where shearwaters are most likely to encounter fishing vessels (for clarity, all data were square-root transformed). BA: Bhattacharyya affinity between the fishing and shearwater UDs. Solid black lines, Falkland Islands management zones; dashed black lines, Argentinian Namuncurá-Burdwood Bank Marine Protected Area (see Fig. 1)

Previously, at-sea surveys documented that sooty shearwaters are concentrated in coastal waters of the Falklands during the austral summer, with relatively little use of the eastern Burdwood Bank (White et al. 2002). However, these surveys did not cover the western part of the bank. Our tracking data show that the vast majority of foraging effort in January was concentrated upslope of the Burdwood Bank shelf-break, especially on its western and southern sides. Oceanographic conditions in the ACC can differ markedly among years along the southern edge of the Patagonian Shelf (Combes \& Matano 2018), and we expect that the distribution of sooty shearwaters could also vary in response. Nonetheless, as noted above, tracking has shown that Burdwood Bank is used by sooty shearwaters from Kidney Island across years and throughout the breeding season, especially during incubation (Hedd et al. 2014). Given that Kidney Island is the largest sooty shearwater colony in the Falklands and possibly in the Atlantic (Clark et al. 2019), this makes Burdwood Bank a key foraging area for Atlantic sooty shearwaters. GLS tracking also indicated that while space use by male and female sooty shearwaters from Kidney Island differs during some breeding stages, use was similar during chick-rearing (Hedd et al. 2014). Our results echo that finding; the only substantive sexual difference we found in the distribution was that trips made to coastal waters to the west of Kidney Island were all by males.

Predictions from our habitat selection models (Fig. 4) indicated areas where untracked sooty shearwaters originating from around 20 smaller colonies in the Falklands archipelago (Poncet et al. 2012, Clark et al. 2019) and from additional colonies on islands off Tierra del Fuego (Croxall \& Wood 2002, Lawton et al. 2006) might forage during incubation and chickrearing, assuming that their habitat preferences are similar to those of birds from Kidney Island and that we used reasonable proxies for their choice of foraging areas. However, we acknowledge that this extrapolation to other colonies assumes that accessibility to different areas would be similar to the birds from Kidney. Because our results indicate that this area provides suitable habitat, it is possible that birds from more distant colonies also forage on Burdwood Bank, perhaps occupying the eastern end more frequently than birds from Kidney. Alternatively, sooty shearwaters may occupy mutually exclusive, colony-specific foraging areas due to density-dependent com- 
petition (Bolton et al. 2019). Tracking from multiple colonies in the region, including those around Tierra del Fuego, would be needed to resolve this.

Model I was optimised to estimate habitat preference without accessibility constraints. Despite this, the effect of colony distance on habitat selection was of a similar magnitude to that of some environmental covariates, with preference peaking at around $400 \mathrm{~km}$ (Fig. 3). This peak, near the maximum observed foraging range, could arise due to the null model implicitly assumed by assigning pseudo-absences from tracks generated by a first-order vector-autoregressive model (Raymond et al. 2015). Potentially, this model does not capture the fact that many seabird foraging trips are relatively linear, with most time spent at the distal end - a pattern assumed to result from birds using memory to return repeatedly and directly to previously visited prey patches (Weimerskirch 2007). In addition, the negative relationship between intraspecific competition among colony members and colony distance might cause birds to use areas farther from the colony than predicted by the movement model. Alternatively, colony distance could act as a proxy for an important environmental covariate missing from our model. Despite these caveats, Model I clearly shows that birds from Kidney Island disproportionately used cold neritic and shelf-edge waters, with preference peaking bimodally at SSTs of approximately 7.5 and $10^{\circ} \mathrm{C}$ and decreasing rapidly with depth off the shelf.

Although global-scale sooty shearwater migratory movements track seasonal peaks in primary production (Shaffer et al. 2006), we did not find a strong effect of NPP on finer-scale habitat use during late incubation/early chick-rearing. At the mesoscale and greater $(100 \mathrm{~s} \mathrm{~km})$ this may be simply because NPP is negatively correlated with depth in our study area (Wakefield et al. 2014) — that is, an apparent preference for shallow waters could arise due to a true preference for productive waters or vice versa. At finer scales, where this correlation breaks down, disproportionately less use of more productive areas may have resulted because the satellite-derived NPP indices may not adequately resolve subsurface NPP. Falabella et al. (2017) suggested that NPP at intermediate depths on Burdwood Bank might be greater than at the surface, especially at the shelf-break front, which forms along the western and southern flanks of the bank, where nutrients are supplied by the Falklands Current (Piola et al. 2018). Sub-mesoscale habitat associations identified among wintering sooty shearwaters to date have all been linked either to the habitat requirements of prey species or pro- cesses that physically aggregate prey (e.g. McClatchie et al. 1989, Phillips et al. 2018, Carvalho \& Davoren 2019). Similarly, a preference for the shelf-edge could also arise due to the shelf-break fronts causing prey to aggregate there (Lovrich \& Thiel 2011).

\subsection{Dive behaviour and potential prey}

Sooty shearwater dives recorded during our study were shallower than those reported in 2 previous TDR studies on sooty shearwaters breeding in New Zealand. The mean depth of dives beyond $1 \mathrm{~m}$ in our study was 2.5 vs. $6.9 \mathrm{~m}$ reported by Dunphy et al. (2015), while dives deeper than $2.5 \mathrm{~m}$ in our study averaged $9.5 \mathrm{~m}$ vs. $15.9 \mathrm{~m}$ reported by Shaffer et al. (2009). These discrepancies could be due to methodological differences. Shaffer et al. (2009) recorded chick-rearing birds at a resolution of 24 or $32 \mathrm{~s}$. In common with similar studies (e.g. Shoji et al. 2016), we found that maximum dive depth is strongly correlated with dive duration, so there will be an increasing bias towards detecting deep dives, and therefore overestimating mean dive depths, as sampling interval increases. Similarly, while Dunphy et al. (2015) recorded dives at the same temporal resolution as our study $(1 \mathrm{~Hz})$, they recorded depth to $\pm 1 \mathrm{~m}$ vs. $0.1 \mathrm{~m}$ in our case. Hence, shallow dives may not have been detected. Sooty shearwaters may therefore make many more short, shallow dives than previously reported. Indeed, we did not consider dives to $<1 \mathrm{~m}$ depth in our analysis, so our data may underestimate the time that sooty shearwaters spend in the upper metre of the water column. In addition, the TDRs themselves could introduce bias by hampering normal behaviour (Vandenabeele et al. 2015). Devices similar those used in our study impacted chick growth, and ultimately fledging mass, when deployed for long durations during the breeding season on sooty shearwaters in New Zealand (Adams et al. 2009). Although the devices used in our study were smaller (6.7 vs. $11 \mathrm{~g}$ ), sooty shearwater tarsi are highly laterally compressed to reduce hydrodynamic resistance (Kuroda 1954), so any leg-mounted device could inhibit foot-propelled diving. If this is so, true dive durations, frequencies and depths could be greater than our study and others report. Moreover, it should be cautioned that our dive results are based on data from only 10 birds, so further study would be required to confirm how representative our results are of the population as a whole.

It is largely unknown what sooty shearwaters prey upon in the Southwest Atlantic, but our results give some indication of likely taxa. In New Zealand, the 
diets of breeding adults and their offspring are dominated by swarming crustaceans, including the coastal euphausiid Nyctiphanes australis and the squat lobster Munida gregaria, with squid (typically ommastrephids) and fish (typically myctophids) making up a lesser proportion (McClatchie et al. 1989, Weimerskirch \& Sagar 1996, Cruz et al. 2001). The diets of non-breeding sooty shearwaters, sampled in disparate locations in the Pacific and Atlantic, tend to be more dominated by forage fish but also include crustaceans, squid and hydrozoans (e.g. Brown et al. 1981, Shiomi \& Ogi 1992, Petry et al. 2008). In common with New Zealand-breeding sooty shearwaters (Shaffer et al. 2009), birds in our study dove predominantly during daylight hours, and dives were deeper during the day, indicating that foraging success is contingent in part on ambient light (Wilson et al. 1993) and that targeted prey may be deeper in the water column during the day. In addition, dive activity peaked just after dawn and before dusk. Crepuscular dive activity by seabirds indicates predation on vertically migrating species, such as zooplankton or consumers tracking zooplankton prey (Shaffer et al. 2009, Regular et al. 2010). Sooty shearwaters have been observed foraging amid surface swarming $\mathrm{Mu}$ nida sp. $10 \mathrm{~km}$ off East Falkland during late March (Bourne 1975), and on several occasions, we found regurgitated $M$. gregaria near sooty shearwater burrows in the study colony, indicating that this species may be targeted during chick provisioning.

\subsection{Foraging behaviour- Atlantic vs. Pacific breeders}

For reasons that are unclear, populations of sooty shearwaters in the Pacific declined between the 1960s-1970s and the 1990s-2000s, while those in the Falklands increased over that period and have apparently continued to do so (Scott et al. 2008, Newman et al. 2009, Clark et al. 2019). It is pertinent therefore to ask whether our results suggest any mechanisms that could contribute to these differing trajectories. Both habitat selection and space use by Falklands birds tracked during our study contrasted markedly with that of chick-rearing birds tracked from colonies around New Zealand. The latter used not only neritic and shelf slope waters (depth $<1500 \mathrm{~m}, \mathrm{SST} 13-17^{\circ} \mathrm{C}_{i}$ Shaffer et al. 2009), but also cold oceanic waters (depth $3000-5000 \mathrm{~m}, \mathrm{SST} 2-4^{\circ} \mathrm{C}$ ) in roughly similar proportions. Ship-based observations indicated spatiotemporal patterns. During austral summer, sooty shearwaters were present in oceanic waters in the southern Indian and Pacific Oceans between 45 and $180^{\circ} \mathrm{E}$ at least as far south as $65^{\circ} \mathrm{S}$, whereas in the Southwest Atlantic, they rarely occurred south of the Patagonian Shelf and South Georgia, and almost never in oceanic waters south of $57^{\circ} \mathrm{S}$ (Ropert-Coudert et al. 2014).

A further difference is that birds tracked from New Zealand made a combination of short (mean \pm SD: $515 \pm 248 \mathrm{~km}$ from the colony) and long trips (1970 \pm $930 \mathrm{~km}$ ). Such a 'dual foraging' strategy has been hypothesised to arise due to parents prioritising chick provisioning on short trips and self-maintenance on longer trips (Weimerskirch 1998). In contrast, birds from the Falklands predominantly made trips that would qualify as short for New Zealand birds (396.0 \pm $22.6 \mathrm{~km}$ ). In addition, 4 birds also made a few even shorter coastal trips $(63.8 \pm 50.9 \mathrm{~km})$. This difference could be due to differing central-place constraints. The New Zealand birds were tracked while raising 30-75 d old chicks, which can be left unattended for longer than chicks in our study (aged $<10 \mathrm{~d}$ ). However, most birds in our study were still incubating, and therefore able to make longer trips, and GLS tracking indicated that birds from Kidney Island continue to make relatively short trips throughout chickrearing (Hedd et al. 2014). Hence, it may be that trip duration reflects prey distribution (Phillips et al. 2009), with largely monomodal trip lengths arising among the birds tracked in our study because the majority of foraging effort was concentrated at one bathymetric feature. In either case, we hypothesise that longer trips from New Zealand indicate that birds have greater foraging costs than at the Falklands, and that this may be one cause of differing population growth rates between the 2 regions. This hypothesis could be tested by modelling the relationship between demographic rates and energetic expenditure or its proxies such as foraging range, within and between these 2 regions (e.g. Fayet et al. 2017). The latter may also depend on competition and breeding stage (Wakefield et al. 2011), so such a study would ideally involve data collection during different breeding stages, at multiple colonies of a range of sizes within the 2 regions. In addition, other impacts on demographic rates, such as bycatch, resource availability and climatic variability, should also be considered (e.g. Genovart et al. 2013, Pardo et al. 2017).

\subsection{Exposure to bycatch risk}

It has been estimated that 1-13 million sooty shearwaters were bycaught in the second half of the $20^{\text {th }}$ 
century (Uhlmann et al. 2005), but the extent to which this contributed to widespread population declines in the Pacific is unclear (Newman et al. 2009). Sooty shearwaters are caught by longlines relatively infrequently because baits are often too large for them to swallow (Uhlmann 2003). In contrast, they are very susceptible to entanglement and bycatch in driftnets, due to their pursuit-diving behaviour (Uhlmann et al. 2005, Newman et al. 2009). An international moratorium is thought to have greatly reduced this threat, but sooty shearwaters are also bycaught by trawlers (González-Zevallos et al. 2007, Black 2010, Kuepfer et al. 2018). We found low similarity between the estimated distributions of longliners or trawlers and foraging sooty shearwaters around the Falklands during late incubation and early chickrearing, perhaps because fishing effort is relatively low in January. Sooty shearwaters have frequently been observed around longliners operating on Burdwood Bank inside the FICZ and FOCZ, especially trying to take baits during setting (Otley et al. 2007), but mitigation measures introduced in 2006 may account for the fact that there have been no gearrelated mortalities in the Falklands fishery since 2007 (Falkland Islands Government 2017). Sooty shearwaters were more likely to encounter trawlers than other types of fishing vessels, especially on the western shelf slope of Burdwood Bank, inside the Argentine EEZ and in coastal waters east of the Falkland Islands archipelago, during this period. An analysis similar to ours, carried out in the North Atlantic, showed that the areas of high spatial overlap between shearwaters and fishing vessels correspond with areas where bycatch occurs most frequently (Hatch et al. 2016). Data on sooty shearwater bycatch on the Patagonian Shelf are limited (possibly due to previously poor observer effort), but incidental mortalities of sooty shearwaters were recorded in the Falkland calamari fleet around the Falkland Islands in late September 2009 (7 birds) and 2013 (3 birds), early October 2017 (12 birds) and late September/ early October 2018 (36 birds) (FIFD 2009, Black 2010, Winter 2018, Falkland Islands Government unpubl. data), and in Argentinian waters in fall in the mid1990s (Gandini et al. 1999) and in April 2005 (González-Zevallos et al. 2007). These periods correspond with the departure and return of birds at the colony (Hedd et al. 2012), so sooty shearwaters would remain vulnerable to bycatch in trawl fisheries in the area.

Measures already in place in Falkland trawl fisheries aimed at preventing collisions, such as birdscaring devices and the avoidance of discard dis- charge during hauling and shooting, may have contributed to reducing shearwater bycatch (Kuepfer et al. 2018). Nonetheless, given that mortality may be difficult to observe and therefore be underestimated, it would be prudent to determine exactly how and where sooty shearwaters are impacted by trawlers (Uhlmann 2003, Quintin 2014, Kuepfer 2017). Trawling in Falklands waters generally occurs at $\geq 70 \mathrm{~m}$ depth, yet we found that sooty shearwaters rarely dived deeper than $30 \mathrm{~m}$ (Fig. 6). Hence, if they are caught underwater this must either occur on the rare occasions when they dive very deep, or when the trawl is shot or hauled, which might go unobserved. They are also killed and injured by colliding with trawl warps, but this is underreported (Watkins et al. 2008).

Our analysis was based on only 20 shearwaters tracked during 2 wk in late incubation/early chickrearing and only during 1 breeding season, when fishing effort in the Falkland Islands is relatively low (Falkland Islands Government 2019). In order to assess sub-mesoscale patterns of bycatch risk more completely, it would be necessary to extend tracking and analysis to include the remainder of the year, when birds range through areas exploited by multiple fisheries in both the southern and northern hemispheres (Hedd et al. 2012). For example, sooty shearwaters from the Falklands suffer appreciable mortality in gillnet fisheries off the east coast of North America (Hatch 2018). Open access to fishing data from the GFW project (Kroodsma et al. 2018) make year-round analyses much more practicable than in the past, but tracking shearwaters accurately year round remains challenging.

\subsection{Importance of Burdwood Bank}

Sooty shearwaters tracked during our study showed consistent use of Burdwood Bank. This highproductivity feature hosts a diverse and abundant benthic fauna (Schejter et al. 2016) and has previously been noted as an important foraging area for seabirds breeding at South Georgia (Croxall \& Wood 2002, Falabella et al. 2009). Black-browed albatrosses from the world's second largest colony of this species, on Beauchene Island, also forage in large numbers over the bank (P. Catry unpubl. data), and at least 33 other pelagic seabird species forage there regularly, including 14 Falkland Islands-breeding species, 5 Endangered species and 5 Vulnerable species (Table S7). For example, rockhopper penguins Eudyptes chrysocome, which are declining in the 
Falklands, use the bank throughout the year, while wandering albatrosses use the surrounding shelf slope, predominantly in the summer (Croxall \& Wood 2002, White et al. 2002).

Given the high abundance and diversity of pelagic seabirds that occur on Burwood Bank, and its crucial importance to the Atlantic sooty shearwater population, seabirds should be given due consideration in any assessments of the conservation value of this feature. The eastern half of Burdwood Bank lies within the FOCZ (Fig. 1). The Falkland Islands Government limits fishing there to a single longline vessel, operating on the bank from spring through autumn, targeting Patagonian toothfish Dissostichus eleginoides. Argentina also claims the whole of the Burdwood Bank as part of its EEZ and unilaterally declared a marine protected area (the Namuncurá-Burdwood Bank MPA) on the bank delimited by the $200 \mathrm{~m}$ isobath (Fig. 1). Argentina does not permit fishing in the 'Core' and 'Buffer' (inner) zones of this MPA (Schejter et al. 2016), but may apparently do so with some restrictions in its outer zone (Falabella et al. 2017). These measures may afford some protection to sooty shearwaters, but our data indicate that areabased protection would be most effective if it also included the shelf break on the southern and western flanks of the bank.

Acknowledgements. This study was funded by the Falkland Islands Government (FIG), the Natural Environment Research Council (grant NE/M017990/1), the Portuguese Foundation for Science and Technology (strategic project MARE - grant number UID/MAR/04292/2019) and through the grant awarded to L.C. (FCT-SFRH/BPD/89904/2012) and the Seabird Group. Logistical support was provided by the South Atlantic Environmental Research Institute. We are grateful to Scott Shaffer for advising us on logger attachment methods; to Global Fishing Watch for providing early access to fishing effort data for 2017 and 2018; to FIG, CapMarine and MIRAG observers for providing data on sooty shearwaters bycatch; and to Jason Matthiopoulos for providing guidance and support.

\section{LITERATURE CITED}

Aarts G, MacKenzie M, McConnell B, Fedak M, Matthiopoulos J (2008) Estimating space-use and habitat preference from wildlife telemetry data. Ecography 31: 140-160

*Acha EM, Mianzan HW, Guerrero RA, Favero M, Bava J (2004) Marine fronts at the continental shelves of austral South America: physical and ecological processes. J Mar Syst 44:83-105

Adams J, Scott D, McKechnie S, Blackwell G, Shaffer SA, Moller H (2009) Effects of geolocation archival tags on reproduction and adult body mass of sooty shearwaters (Puffinus griseus). N Z J Zool 36:355-366

Adams J, MacLeod C, Suryan RM, Hyrenbach KD, Harvey
JT (2012) Summer-time use of west coast US National Marine Sanctuaries by migrating sooty shearwaters (Puffinus griseus). Biol Conserv 156:105-116

* Anderson ORJ, Small CJ, Croxall JP, Dunn EK, Sullivan BJ, Yates O, Black A (2011) Global seabird bycatch in longline fisheries. Endang Species Res 14:91-106

Baylis AMM, Tierney M, Orben RA, Warwick-Evans V and others (2019) Important at-sea areas of colonial breeding marine predators on the Southern Patagonian Shelf. Sci Rep 9:8517

BirdLife International (2019) Species factsheet: Ardenna grisea. www.birdlife.org (accessed on 21 October 2019)

Black A (2010) An assessment of seabird bycatch in Falkland Islands trawl fisheries July 2009 to June 2010. Falkland Islands Fisheries Department, Stanley

Bolton M, Conolly G, Carroll M, Wakefield Ewan D, Caldow $R$ (2019) A review of the occurrence of inter-colony segregation of seabird foraging areas and the implications for marine environmental impact assessment. Ibis 161: 241-259

Bourne W (1975) Birds feeding on lobster-krill off the Falkland Islands. Sea Swallow 24:22-23

Briggs KT, Chu EW (1986) Sooty shearwaters off California: distribution, abundance and habitat use. Condor 88: 355-364

Briggs KT, Tyler WB, Lewis DB, Carlson DR (1987) Bird communities at sea off California: 1975 to 1983. Cooper Ornithological Society, Lawrence, KS

Brooke ML (2004) The food consumption of the world's seabirds. Proc R Soc B 271:S246-S248

Brown R (1986) Revised atlas of eastern Canadian seabirds. Bedford Institute of Oceanography, Canadian Wildlife Service, Ottawa

* Brown RGB, Barker SP, Gaskin DE, Sandeman MR (1981) The foods of great and sooty shearwaters Puffinus gravis and $P$. griseus in eastern Canadian waters. Ibis 123:19-30

Calenge C (2006) The package 'adehabitat' for the R software: a tool for the analysis of space and habitat use by animals. Ecol Model 197:516-519

Calenge C (2015) Analysis of animal movements in R: the adehabitatLT Package. R Package Version 0.3.25. https:// CRAN.r-project.org/web/packages/adehabitatLT/index. html

Carvalho PC, Davoren GK (2019) Associations of nonbreeding shearwater species on the northeastern Newfoundland coast. Mar Ecol Prog Ser 627:1-12

* Clark TJ, Matthiopoulos J, Bonnet-Lebrun AS, Campioni L and others (2019) Integrating habitat and partial survey data to estimate the regional population of a globally declining seabird species, the sooty shearwater. Glob Ecol Conserv 17:e00554

Clucas R, Moller H, Bragg C, Fletcher D, Lyver P, Newman J (2012) Rakiura Māori muttonbirding diaries: monitoring trends in tītī (Puffinus griseus) abundance in New Zealand. N Z J Zool 39:155-177

* Collet J, Patrick SC, Weimerskirch H (2015) Albatrosses redirect flight towards vessels at the limit of their visual range. Mar Ecol Prog Ser 526:199-205

Combes V, Matano RP (2018) The Patagonian shelf circulation: drivers and variability. Prog Oceanogr 167:24-43

Croxall JP, Wood AG (2002) The importance of the Patagonian Shelf for top predator species breeding at South Georgia. Aquat Conserv 12:101-118

Cruz JB, Lalas C, Jillett JB, Kitson JC and others (2001) Prey spectrum of breeding sooty shearwaters (Puffinus 
griseus) in New Zealand. N Z J Mar Freshw Res 35: 817-829

Dias MP, Martin R, Pearmain EJ, Burfield IJ and others (2019) Threats to seabirds: a global assessment. Biol Conserv 237:525-537

Dunphy BJ, Taylor GA, Landers TJ, Sagar RL, Chilvers BL, Ranjard L, Rayner MJ (2015) Comparative seabird diving physiology: first measures of haematological parameters and oxygen stores in three New Zealand Procellariiformes. Mar Ecol Prog Ser 523:187-198

Falabella V, Campagna C, Croxall J, Wildlife Conservation Society (eds) (2009) Atlas del Mar Patagónico: especies y espacios $=$ Atlas of the Patagonian Sea. Wildlife Conservation Society, Buenos Aires

Falabella V, Caille G, Campagna C, Lovrich G, Moreno D, Piola AR, Zelaya D (2017) Área Marina Protegida Namuncurá - Banco Burdwood. Contribuciones para la línea de base y el plan de manejo. Jefatura de Gabinete de Ministros, Buenos Aires

FIFD (Falkland Islands Fisheries Department) (2009) FIFD observer report 793. Falkland Islands Fisheries Department, Stanley

Falkland Islands Government (2017) Fisheries Department Fisheries Statistics, Vo 21, 2016. FIG Fisheries Department, Stanley

Falkland Islands Government (2019) Fisheries Department Fisheries Statistics, Volume 23，2018. FIG Fisheries Department, Stanley

Fayet AL Freeman R, Anker-Nilssen T, Diamond A and others (2017) Ocean-wide drivers of migration strategies and their influence on population breeding performance in a declining seabird. Curr Biol 27:3871-3878.e3

Fieberg J, Kochanny CO (2005) Quantifying home-range overlap: the importance of the utilization distribution. J Wildl Manag 69:1346-1359

Fridolfsson AK, Ellegren H (1999) A simple and universal method for molecular sexing of non-ratite birds. J Avian Biol 30:116-121

Gandini PA, Frere E, Pettovello AD, Cedrola PV (1999) Interaction between Magellanic penguins and shrimp fisheries in Patagonia, Argentina. Condor 101:783-789

* Genovart M, Sanz-Aguilar A, Fernández-Chacón A, Igual JM, Pradel R, Forero MG, Oro D (2013) Contrasting effects of climatic variability on the demography of a transequatorial migratory seabird. J Anim Ecol 82:121-130

González-Zevallos D, Yorio P, Caille G (2007) Seabird mortality at trawler warp cables and a proposed mitigation measure: a case of study in Golfo San Jorge, Patagonia, Argentina. Biol Conserv 136:108-116

*Hatch JM (2018) Comprehensive estimates of seabirdfishery interactions for the US Northeast and midAtlantic. Aquat Conserv 28:182-193

Hatch JM, Wiley D, Murray KT, Welch L (2016) Integrating satellite-tagged seabird and fishery-dependent data: a case study of great shearwaters (Puffinus gravis) and the U.S. New England sink gillnet fishery. Conserv Lett 9: 43-50

Hedd A, Montevecchi WA, Otley H, Phillips RA, Fifield DA (2012) Trans-equatorial migration and habitat use by sooty shearwaters Puffinus griseus from the South Atlantic during the nonbreeding season. Mar Ecol Prog Ser 449:277-290

Hedd A, Montevecchi WA, Phillips RA, Fifield DA (2014) Seasonal sexual segregation by monomorphic sooty shearwaters Puffinus griseus reflects different reproduc- tive roles during the pre-laying period. PLOS ONE 9: e85572

Hijmans RJ (2018) Raster: Geographic Data Analysis and Modeling. R package version 2.7-15. https:/CRAN.Rproject.org/package=raster

Hyrenbach KD, Veit RR (2003) Ocean warming and seabird communities of the southern California Current System (1987-98): response at multiple temporal scales. Deep Sea Res II 50:2537-2565

Kim YJ, Gu C (2004) Smoothing spline Gaussian regression: more scalable computation via efficient approximation. J R Stat Soc Ser B Stat Methodol 66:337-356

Kroodsma DA, Mayorga J, Hochberg T, Miller NA and others (2018) Tracking the global footprint of fisheries. Science 359:904-908

Kuepfer A (2017) An assessment of seabird by-catch in Falkland Islands trawl fisheries, July 2016 to June 2017. Falkland Islands Fisheries Department, 1-30, Stanley

Kuepfer A, Croft S, Tierney M, Blake D, Goyot L (2018) Falkland Islands National Plan of Action of reducing incidental catch of seabirds in trawl fisheries (FI NPOAS-T-2019). Fisheries Department, Directorate of Natural Resources, Falkland Islands Government, Stanley

Kuroda N (1954) On the classification and phylogeny of the order Tubinares, particularly the Shearwaters (Puffinus), with special considarations [sic] on their osteology and habit differentiation. Kuroda N, Tokyo

Lascelles BG, Taylor PR, Miller MGR, Dias MP and others (2016) Applying global criteria to tracking data to define important areas for marine conservation. Divers Distrib 22:422-431

*Lawton K, Robertson G, Kirkwood R, Valencia J, Schlatter R, Smith D (2006) An estimate of population sizes of burrowing seabirds at the Diego Ramirez archipelago, Chile, using distance sampling and burrow-scoping. Polar Biol 29:229-238

光Le Bot T, Lescroël A, Grémillet D (2018) A toolkit to study seabird-fishery interactions. ICES J Mar Sci 75: 1513-1525

Longhurst A (1998) Ecological geography of the sea. Academic Press, San Diego, CA

Lovrich G, Thiel M (2011) Ecology, physiology, feeding and trophic role of squat lobsters. In: Poore G, Ahyong S, Taylor J (eds) The biology of squat lobsters. CSIRO Publishing, Collingwood, p 183-222

* Lyver P. O'B, Moller H, Thompson C (1999) Changes in sooty shearwater Puffinus griseus chick production and harvest precede ENSO events. Mar Ecol Prog Ser 188: 237-248

*McClatchie S, Hutchinson D, Nordin K (1989) Aggregation of avian predators and zooplankton prey in Otago shelf waters, New Zealand. J Plankton Res 11:361-374

* Merkel B, Phillips RA, Descamps S, Yoccoz NG, Moe B, Strøm H (2016) A probabilistic algorithm to process geolocation data. Mov Ecol 4:26

*Michelot T, Langrock R, Patterson TA (2016) MoveHMM: an $\mathrm{R}$ package for the statistical modelling of animal movement data using hidden Markov models. Methods Ecol Evol 7:1308-1315

Nakagawa S, Johnson PCD, Schielzeth H (2017) The coefficient of determination $\mathrm{R}^{2}$ and intra-class correlation coefficient from generalized linear mixed-effects models revisited and expanded. J R Soc Interface 14:20170213

Newman J, Scott D, Moller H, Fletcher D (2008) A population and harvest intensity estimate for sooty shearwater, 
Puffinus griseus, on Taukihepa (Big South Cape), New Zealand. Pap Proc R Soc Tasman 142:177-184

*Newman J, Scott D, Bragg C, McKechnie S, Moller H, Fletcher D (2009) Estimating regional population size and annual harvest intensity of the sooty shearwater in New Zealand. N Z J Zool 36:307-323

Otley HM, Reid TA, Pompert J (2007) Trends in seabird and Patagonian toothfish Dissostichus eleginoides longliner interactions in Falkland Island waters, 2002/03 and 2003/04. Mar Ornithol 35:47-55

Pardo D, Forcada J, Wood AG, Tuck GN and others (2017) Additive effects of climate and fisheries drive ongoing declines in multiple albatross species. Proc Natl Acad Sci USA 114:E10829-E10837

* Petry MV, da Silva Fonseca VS, Krüger-Garcia L, da Cruz Piuco R, Brummelhaus J (2008) Shearwater diet during migration along the coast of Rio Grande do Sul, Brazil. Mar Biol 154:613-621

* Phillips EM, Horne JK, Adams J, Zamon JE (2018) Selective occupancy of a persistent yet variable coastal river plume by two seabird species. Mar Ecol Prog Ser 594:245-261

* Phillips JH (1963) The pelagic distribution of the sooty shearwater Procellaria grisea. Ibis 105:340-353

* Phillips RA, Xavier JC, Croxall JP (2003) Effects of satellite transmitters on albatrosses and petrels. Auk 120: 1082-1090

* Phillips RA, Silk JRD, Croxall JP, Afanasyev V, Briggs DR (2004) Accuracy of geolocation estimates for flying seabirds. Mar Ecol Prog Ser 266:265-272

Phillips RA, Wakefield EW, Croxall JP, Fukuda A, Higuchi H (2009) Albatross foraging behaviour: no evidence for dual foraging, and limited support for anticipatory regulation of provisioning at South Georgia. Mar Ecol Prog Ser 391:279-292

Piola AR, Palma ED, Bianchi AA, Castro BM and others (2018) Physical oceanography of the SW Atlantic Shelf: a review. In: Hoffmeyer M, Sabatini M, Brandini F, Calliari D, Santinelli N (eds) Plankton ecology of the southwestern Atlantic. Springer, Cham, p 37-56

Poncet S, Passfield K, Rexer-Huber K (2012) Burrowing petrel surveys: Top and Bottom Islands and Tussac Point in Port William and Sophie and Amy Islands in Port Pleasant. Beaver Island LandCare, Stanley

Quintin MJ (2014) An assessment of seabird bycatch in Falkland Islands trawl fisheries July 2013 to June 2014. Falkland Islands Fisheries Department, Stanley

R Core Team (2018) R: a language and environment for statistical computing, ver. 3.5.1. R Foundation for Statistical Computing, Vienna

Raymond B, Lea MA, Patterson T, Andrews-Goff V and others (2015) Important marine habitat off east Antarctica revealed by two decades of multi-species predator tracking. Ecography 38:121-129

Raymond B, Wotherspoon S, Jonsen I, Reisinger RR (2018) Availability: estimating geographic space available to animals based on telemetry data. $\mathrm{R}$ package version 0.13.1. https://github.com/AustralianAntarcticDataCentre/ availability

Regular PM, Davoren GK, Hedd A, Montevecchi WA (2010) Crepuscular foraging by a pursuit-diving seabird: tactics of common murres in response to the diel vertical migration of capelin. Mar Ecol Prog Ser 415:295-304

Reyes-Arriagada R, Campos-Ellwanger P, Schlatter RP, Baduini C (2007) Sooty shearwater (Puffinus griseus) on Guafo Island: the largest seabird colony in the world?
Biodivers Conserv 16:913-930

* Roberts A, Silverman E, Gifford S (2018) Sample size considerations for satellite telemetry and animal distributions. J Wildl Manag 82:1536-1544

Rodríguez A, Arcos JM, Bretagnolle V, Dias MP and others (2019) Future directions in conservation research on petrels and shearwaters. Front Mar Sci 6:94

Ropert-Coudert Y, Hindell MA, Phillips R, Charrassin JB, Trudelle L, Raymond B (2014) Biogeographic patterns of birds and mammals. In: De Broyer C, Koubbi P, Griffiths HJ, Raymond B and others (eds) Biogeographic atlas of the Southern Ocean. Scientific Committee on Antarctic Research, Cambridge, p 364-387

* Santora JA, Sydeman WJ (2015) Persistence of hotspots and variability of seabird species richness and abundance in the southern California Current. Ecosphere 6:art214

* Schejter L, Rimondino C, Chiesa I, Díaz de Astarloa JM and others (2016) Namuncurá Marine Protected Area: an oceanic hot spot of benthic biodiversity at Burdwood Bank, Argentina. Polar Biol 39:2373-2386

* Schoombie S, Dilley BJ, Davies D, Ryan PG (2018) The foraging range of great shearwaters (Ardenna gravis) breeding on Gough Island. Polar Biol 41:2451-2458

Scott D, Scofield P, Hunter C, Fletcher D (2008) Decline of sooty shearwaters, Puffinus griseus, on The Snares, New Zealand. Pap Proc R Soc Tasman 142:185-196

* Shaffer SA, Tremblay Y, Awkerman JA, Henry RW and others (2005) Comparison of light- and SST-based geolocation with satellite telemetry in free-ranging albatrosses. Mar Biol 147:833-843

Shaffer SA, Tremblay Y, Weimerskirch H, Scott D and others (2006) Migratory shearwaters integrate oceanic resources across the Pacific Ocean in an endless summer. Proc Natl Acad Sci USA 103:12799-12802

* Shaffer SA, Weimerskirch H, Scott D, Pinaud D and others (2009) Spatiotemporal habitat use by breeding sooty shearwaters Puffinus griseus. Mar Ecol Prog Ser 391: 209-220

Shiomi K, Ogi H (1992) Feeding ecology and body size dependence on diet of the sooty shearwater, Puffinus griseus, in the North Pacific. Proc NIPR Symp Polar Biol 5:105-113

Shoji A, Dean B, Kirk H, Freeman R, Perrins CM, Guilford T (2016) The diving behaviour of the Manx shearwater Puffinus puffinus. Ibis 158:598-606

* Soanes LM, Arnould JPY, Dodd SG, Sumner MD, Green JA (2013) How many seabirds do we need to track to define home-range area? J Appl Ecol 50:671-679

Uhlmann S (2003) Fisheries bycatch mortalities of sooty shearwaters (Puffinus griseus) and short-tailed shearwaters (P. tenuirostris). DOC Science Internal Series 92. Department of Conservation, Wellington

* Uhlmann S, Fletcher D, Moller H (2005) Estimating incidental takes of shearwaters in driftnet fisheries: lessons for the conservation of seabirds. Biol Conserv 123:151-163

van Etten J (2017) R Package gdistance: distances and routes on geographical grids. J Stat Softw 76:1-21

* Vandenabeele SP, Grundy E, Friswell MI, Grogan A, Votier SC, Wilson RP (2014) Excess baggage for birds: Inappropriate placement of tags on gannets changes flight patterns. PLOS ONE 9:e92657

*Vandenabeele SP, Shepard ELC, Grémillet D, Butler PJ, Martin GR, Wilson RP (2015) Are bio-telemetric devices a drag? Effects of external tags on the diving behaviour of great cormorants. Mar Ecol Prog Ser 519:239-249 
Wahl TR, Ainley DG, Benedict AH, DeGange AR (1989) Associations between seabirds and water-masses in the northern Pacific Ocean in summer. Mar Biol 103:1-11

Wakefield ED, Phillips RA, Trathan PN, Arata J and others (2011) Habitat preference, accessibility, and competition limit the global distribution of breeding Black-browed Albatrosses. Ecol Monogr 81:141-167

Wakefield ED, Phillips RA, Matthiopoulos J (2014) Habitatmediated population limitation in a colonial centralplace forager: The sky is not the limit for the blackbrowed albatross. Proc R Soc B 281:20132883

Wakefield ED, Owen E, Baer J, Carroll MJ and others (2017) Breeding density, fine-scale tracking, and large-scale modeling reveal the regional distribution of four seabird species. Ecol Appl 27:2074-2091

Watkins BP, Petersen SL, Ryan PG (2008) Interactions between seabirds and deep-water hake trawl gear: an assessment of impacts in South African waters. Anim Conserv 11:247-254

Waugh SM, Patrick SC, Filippi DP, Taylor GA, Arnould JPY (2016) Overlap between flesh-footed shearwater Puffinus carneipes foraging areas and commercial fisheries in New Zealand waters. Mar Ecol Prog Ser 551:249-260

Weimerskirch H (1998) How can a pelagic seabird provision its chick when relying on a distant food resource? Cyclic attendance at the colony, foraging decision and body condition in sooty shearwaters. J Anim Ecol 67:99-109

Weimerskirch H (2007) Are seabirds foraging for unpredictable resources? Deep Sea Res II 54:211-223

Weimerskirch H, Sagar PM (1996) Diving depths of sooty shearwaters Puffinus griseus. Ibis 138:786-788

White R, Gillon K, Black A, Reid J (2002) The distribution of seabirds and marine mammals in Falkland Islands waters. Joint Nature Conservation Committee, Peterborough

*Wilson RP, Puetz K, Bost CA, Culik BM, Bannasch R, Reins T, Adelung D (1993) Diel dive depth in penguins in relation to diel vertical migration of prey: whose dinner by candlelight? Mar Ecol Prog Ser 94:101-104

Winter A (2018) Stock assessment of Doryteythis gahi for the 2nd season 2018. Fisheries Department, Directorate of Natural Resources, Falkland Islands Government, Stanley

Wood SN (2004) Stable and efficient multiple smoothing parameter estimation for generalized additive models. J Am Stat Assoc 99:673-686

Wood SN (2017) Generalized additive models: an introduction with $\mathrm{R}, 2^{\text {nd }}$ edn. Chapman and Hall/CRC, Boca Raton, FL

Woods RW (1970) The avian ecology of a tussock island in the Falkland Islands. Ibis 112:15-24

Submitted: February 18, 2020; Accepted: July 22, 2020

Proofs received from author(s): September 16, 2020
Editorial responsibility: Thierry Boulinier, Montpellier, France 